University of Arkansas, Fayetteville

ScholarWorks@UARK

Graduate Theses and Dissertations

8-2018

\title{
The Effect of Tax System Characteristics on Cross-Border Mergers and Acquisitions
}

Jodi Michelle Henley

University of Arkansas, Fayetteville

Follow this and additional works at: https://scholarworks.uark.edu/etd

Part of the Accounting Commons

\section{Citation}

Henley, J. M. (2018). The Effect of Tax System Characteristics on Cross-Border Mergers and Acquisitions. Graduate Theses and Dissertations Retrieved from https://scholarworks.uark.edu/etd/2834

This Dissertation is brought to you for free and open access by ScholarWorks@UARK. It has been accepted for inclusion in Graduate Theses and Dissertations by an authorized administrator of ScholarWorks@UARK. For more information, please contact scholar@uark.edu. 
The Effect of Tax System Characteristics on Cross-Border Mergers and Acquisitions

A dissertation submitted in partial fulfillment

of the requirements for the degree of

Doctor of Philosophy in Business Administration

by

\author{
Jodi Henley \\ Stephen F. Austin State University \\ Bachelor of Business Administration in Accounting, 2010 \\ Stephen F. Austin State University \\ Master of Professional Accountancy, 2010
}

August 2018

University of Arkansas

This dissertation is approved for recommendation to the Graduate Council

T.J. Atwood, PhD

Dissertation Director

Cory Cassell, $\mathrm{PhD}$

Committee Member
Jonathan Shipman, PhD

Committee Member 


\begin{abstract}
Although determinants of cross-border merger and acquisitions (M\&As) have been given substantial attention in the literature, research examining the effect of tax system characteristics on cross-border M\&As is more limited. Cross-border M\&As have substantial tax implications for both the acquiring firm and the target firm. Because firms evaluate investments based on expected after-tax returns, I expect that managers consider potential tax savings or costs in making investment decisions across tax jurisdictions. In this study, I use hand-collected countryyear-level tax system characteristics to examine tax determinants of the volume and direction of cross-border M\&As. I find that tax system characteristics such as controlled foreign corporation provisions, thin capitalization provisions, and the presence of a worldwide versus territorial regime have a significant effect on cross-border M\&A activity.
\end{abstract}




\section{Acknowledgements}

I would like to thank the members of my dissertation committee: TJ Atwood (chair), Cory Cassell, and Jonathan Shipman, as well as Stuart Dearden, Emily Hunt, Josh Hunt and my other $\mathrm{PhD}$ student colleagues for their advice, guidance, and friendship. I also appreciate the invaluable encouragement and support of my family, Aubrey and Kim Henley, Rick and Megan Henley, and Matt Henley. 


\section{Table of Contents}

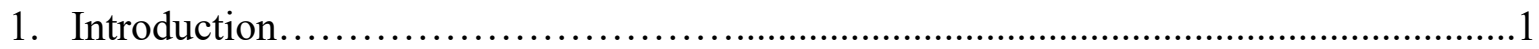

2. Background and Development of Expectations...............................6

3. Research Methodology..................................................... 14

4. Data Sources and Sample Construction.......................................25

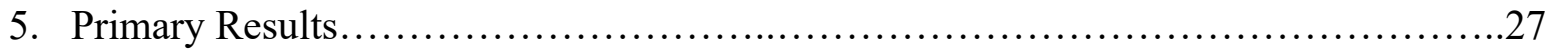

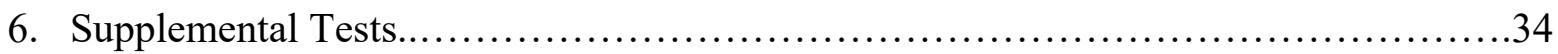

7. Additional Analysis...................................................... 37

8. Conclusion................................................................... 41

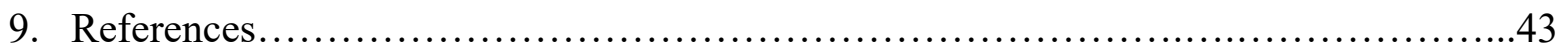

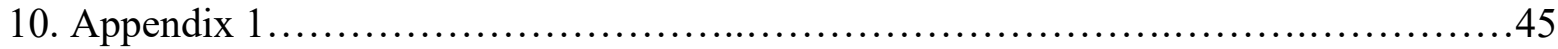

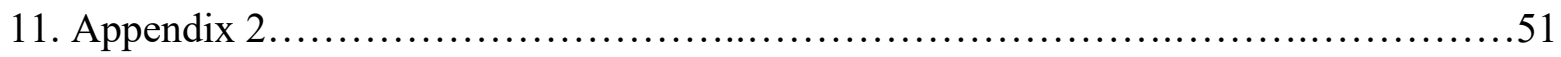


"Over the past four years...Valeant has managed to acquire a slew of U.S. companies worth more than $\$ 30$ billion. The Subcommittee reviewed key deal documents to understand how tax advantages affected Valeant's three largest acquisitions to date, including the 2013 sale of New York-based eye care firm Bausch \& Lomb and the 2015 sale of North Carolina-based drug maker Salix. We learned that in those two transactions alone, Valeant determined it could shave more than $\$ 3$ billion off the target company's [sic] tax bills by integrating them into the Canadian-based corporate group. Those tax savings meant that Valeant's investments in its American targets would have higher returns and pay for themselves more quickly-two key drivers, of course, of any acquisition." - Senator Rob Portman,

Senate Subcommittee on Investigations Chairman

\section{Introduction}

Increasing globalization results in a growing number of cross-border mergers and acquisitions (M\&As). In 2017, JP Morgan's 2018 Global M\&A Outlook states that over 30\% of total M\&A activities were cross-border. Unlike domestic M\&As, cross-border M\&As are subject to additional frictions caused by national boundaries, such as differences in currencies, language, culture, regulations, and macroeconomic factors. Prior research provides evidence that many factors affect the volume and direction of cross-border M\&As, including geographic distance, economic development, exchange rate and stock market returns (Erel et al. 2012), as well as accounting quality (Rossi and Volpin 2004). However, M\&As, and particularly crossborder M\&As, may have far-reaching tax implications for both the acquirer and the target. In fact, the decision to engage in a cross-border M\&A may be primarily tax-motivated, as it can 
facilitate tax avoidance strategies such as advantageously shifting income or expatriating to a tax-preferred jurisdiction.

In the U.S., much of the rhetoric surrounding tax reform suggests that U.S. multinational corporations may not be competitive in the global marketplace, including the market for foreign investments, such as M\&A targets. In July 2015, the U.S. Senate Subcommittee on Investigations conducted a hearing entitled "The effect of the U.S. Tax Code on the Market for Corporate Control and Jobs" in which senators interviewed CEOs and executives from companies that were affected by corporate inversions or foreign takeovers. While an extensive literature examines corporate inversions, they are relatively rare. Bloomberg's Tax Inversion Tracker lists fifty-eight total corporate inversions between 1982 and 2017, inclusive. Since 2004, the Treasury Department has issued four broad sets of regulations to curb the practice, albeit with limited success. However, in curbing corporate inversion practices, some have suggested that U.S. companies are now more vulnerable to foreign takeovers. Consistent with this, the Senate Subcommittee found that the value of foreign takeovers of U.S. companies in 2014 totaled $\$ 275$ billion, double the amount for 2013. A recent analysis by $\mathrm{E} \& \mathrm{Y}$ found that between 2004 and 2014, foreign buyers acquired \$179B more of U.S. companies than U.S. companies acquired in foreign targets. Anecdotally, Salix Pharmaceuticals, a North-Carolina based company, was in talks to complete an acquisition inversion in order to expatriate to Ireland in 2014. However, the plans dissolved when the Treasury Department issued its second set of inversion restrictions in 2014. The halt was lauded as a victory for the Treasury Department. However, only a few months later, Salix Pharmaceuticals was acquired by Canadian Valeant Pharmaceuticals. Once a U.S.-based company, Valeant had successfully completed a corporate 
inversion in 2010 via a reverse-merger with Ontario-based Biovail, prior to the release of the Treasury Department's second set of inversion restrictions.

Despite the importance of tax considerations to cross-border M\&A decisions, extant research on tax effects in cross-border M\&A decisions is largely limited to broad tax system characteristics, such as statutory tax rates (Erel et al. 2012), double-taxation of dividends paid by foreign subsidiaries (Huizinga and Voget 2009), and the U.K.'s and Japan's switches from worldwide to territorial regimes (Feld, Ruf, Scheuering, Schreiber and Voget 2013). However, cross-border M\&A activity presents opportunities for firms to engage in sophisticated tax avoidance, possibly even allowing them to change their tax residence, effectively altering the entire tax jurisdiction to which the post-M\&A firm is subject. Changes to the corporate structure caused by cross-border M\&As can result in changes to the cost of operating the target, as well as changes to the cost of repatriating income from foreign subsidiaries to the acquirer. For this reason, firms are likely to consider multiple tax system characteristics, rather than differences in corporate tax rates alone, in selecting and structuring cross-border M\&As. To improve our understanding of the impact that tax system characteristics have on cross-border M\&A transactions, I examine multiple tax system characteristics, including worldwide and territorial regimes, Controlled Foreign Corporation (CFC) provisions, transfer pricing, thin capitalization regulations, double-taxation relief provisions, and favorable tax treatment of income derived from intellectual property (IP), in addition to differences in statutory tax rates on corporate income and both statutory and treaty withholding rates on dividends paid from the target to the acquirer. 
I exploit variations in tax system characteristics across tax jurisdictions and over time to examine the impact of these characteristics on cross-border M\&As. ${ }^{1}$ I use the $E \& Y$ Worldwide Corporate Tax Guides and the PwC Worldwide Tax Summaries for corporate taxes to handcollect tax system characteristics that I expect will influence after-tax returns to M\&A transactions. ${ }^{2}$ If rational managers evaluate investment opportunities using expected after-tax returns, I expect that acquirers will evaluate potential target firms considering all possible tax costs or synergies that may result from cross-border M\&As. As a result, I expect that tax "synergies" created by differences in tax system characteristics across the acquiring and target firms' countries will affect the flow of cross-border M\&As between the two countries. Using a sample of 55,670 cross-border M\&As across 50 countries between 2006 and 2015, inclusive, I find evidence to suggest that a naïve tax variable, such as the difference in the statutory corporate income tax rate, does not fully explain tax effects on M\&A decisions. I find that tax system characteristics strongly influence the direction of cross-border M\&A, while effects on the volume of M\&A are more ambiguous. Specifically, I find that, when firms from two countries with divergent tax treatments merge, the acquirer is more likely to have a higher statutory tax rate, but less likely to be subject to a worldwide tax regime, CFC provisions, or thin capitalization rules. In addition, I find evidence that firms structure the direction of M\&A to minimize dividend withholding taxes on the repatriation of profits from the target to the acquirer.

\footnotetext{
${ }^{1}$ SDC M\&A database does not contain sufficient information to determine whether the acquired firm will be operated as a subsidiary or as a foreign branch of the acquiring firm, and the tax treatment of the post-M\&A firm often differs according to this designation. M\&As more commonly result in subsidiary structures rather than branch structures (Huizinga and Voget 2009). Therefore, in defining a country's tax system characteristics, I consider the treatment of foreign-source income when the taxpayer is a corporation, the legal structure is a foreign subsidiary (not a foreign branch), and the income is from the active conduct of a business.

${ }^{2}$ I examine tax system characteristics relevant to the taxation of foreign-sourced income, profit-shifting, and avoidance of double-taxation, as well as withholding taxes payable upon transferring dividends across jurisdictions. I focus on these broad characteristics, rather than specific tax rules governing the determination of taxable income (i.e., depreciation rules or relief from losses), as they are likely to capture large changes to the tax treatment of a firm as a result of cross-border M\&A.
} 
I also document that the effects of tax system characteristics on cross-border M\&As differ when the acquirer is located in a worldwide tax regime than when the acquirer is located in a territorial tax regime, consistent with tax system characteristics imposing different costs across tax regimes. In additional analyses, I examine the use of an intermediary firm in a third country and the proportion of cross-border M\&As in which the acquirer gains control of the target firm (i.e. more than 50 percent owned). I find evidence to suggest that cross-border M\&A is more (less) likely to involve a third, intermediary country when the acquirer (target) is located in a worldwide regime and the target (acquirer) is located in a territorial regime. I find strong evidence that the presence of CFC provisions in the acquirer country deters firms, not only in acquiring a target, but in obtaining control of a target.

My study contributes to the body of research examining the determinants of cross-border investment decisions. My study may also be of interest to legislators, as it contributes to our understanding of the potential effects of the recent U.S. tax reform, commonly known as "The Tax Cuts and Jobs Act." ${ }^{3}$ Cross-border M\&A activities both of and by U.S. companies, including those that result in expatriation of U.S. firms (i.e., corporate inversions), were frequently cited as evidence that the U.S. worldwide tax regime put U.S. multinational corporations at a functional disadvantage relative to their foreign counterparts. Supporters of the tax reform state that the current U.S. tax system hinders U.S. firms' ability to compete against similar firms based in lower-tax, territorial jurisdictions and cite U.S. corporate inversions and foreign acquirers targeting U.S. firms as evidence that the U.S. tax burden makes U.S. companies more valuable to foreign acquirers than to domestic acquirers. My study contributes to this debate by empirically demonstrating that tax system characteristics have a significant impact on

\footnotetext{
${ }^{3}$ While commonly referred to as "The Tax Cuts and Jobs Act," the bill is entitled "To provide for reconciliation pursuant to titles II and V of the concurrent resolution on the budget for fiscal year 2018."
} 
a firm's likelihood of investing abroad or likelihood of being acquired by a foreign firm. My results suggest that CFC provisions and thin capitalization rules, both present in the U.S. tax system before and after the reform, may be stronger drivers of the direction of cross-border M\&A than the presence of a worldwide tax system.

The remainder of this paper is organized as follows: section two provides background and development of expectations, section three outlines the research methodology, section four discusses data sources and sample composition, section five presents primary results, section six presents supplemental tests, section seven presents additional analyses, and section eight concludes.

\section{Background and Development of Expectations}

Determinants of Cross-Border M\&As

Determinants of cross-border M\&As have received meaningful attention in both the accounting and finance literatures. Di Giovanni (2005) finds that domestic financial conditions, such as the size of the stock market relative to GDP, increases the number of foreign acquisitions made by firms within a country. Rossi and Volpin (2004) find that firms are more likely to be targeted for M\&As in countries with stronger investor protections and accounting quality, though, as a proportion of total M\&As, cross-border M\&As are less common in these countries. Within cross-border M\&As, the authors find that acquirers are likely to be from countries with stronger investor protections than those in the target country, suggesting that corporate governance may be "imported" through the use of cross-border M\&As. Erel et al. (2012) examine several non-tax determinants of cross-border M\&As, including country-level governance, geographic distance, bilateral trade, currency exchange rate returns, and stock 
market returns. They find that firms acquire more foreign subsidiaries in countries that are geographically close and culturally similar, as well as in countries that are already trading partners. They also find that acquirers strategically acquire targets in response to valuation differences caused by differences in stock market and exchange rate returns, not as a result of pure financial arbitrage, but because valuation differences make cross-border M\&As incrementally more desirable. Though Erel et al. (2012) focus on non-tax determinants of crossborder M\&As, they also consider the influence of statutory tax rates on cross-border M\&As. They find that firms are more likely to acquire targets in countries with a lower statutory corporate income tax rate, which provides some evidence that managers strategically consider tax costs in making cross-border M\&A decisions.

In addition to the findings in Erel et al. (2012), other studies examine the effect of statutory tax rates and broad tax reform on cross-border M\&As. Feld et al. (2013) examine foreign acquisitions by Japanese and British firms around the 2009 tax reforms which resulted in each country moving from a worldwide to a territorial regime. They find that foreign acquisitions by Japanese and British firms increased following the reform, which they interpret as evidence that worldwide tax regimes reduce the competitiveness of firms in the international market for corporate control. Huizinga and Voget (2009) examine 917 cross-border M\&As between firms in European countries, Japan, and the United States that occurred from 1985 through 2004. For countries in their sample, the double tax burden on foreign profits repatriated to a parent firm is estimated as a function of the target country's statutory corporate income tax rate, the acquirer country's statutory corporate income tax rate, the withholding tax rate on dividends repatriated to the parent country, and the target and acquiring firms' relative 
profitability. ${ }^{4}$ The authors find that, as the rate of double tax liability increases, the likelihood that a firm acquires a target decreases, consistent with firms adopting an organization structure that minimizes their double tax liability. ${ }^{5}$ In an additional paper, the authors further examine double taxation's impact on merger pricing, and find that the increased tax burden is fully capitalized into merger premiums, suggesting that the target firm's shareholders bear the increased tax burden (Huizinga, Voget, and Wager 2012).

As discussed above, extant research on tax determinants of cross-border M\&As has primarily examined the effect of statutory corporate income tax rates, despite evidence to suggest that other tax system characteristics are important determinants of expected returns. However, this narrow focus ignores several meaningful tax characteristics that are also likely to influence foreign investment decisions, including cross-border M\&As. Atwood, Huston, and Wallace (2015) analytically model expected home country tax payable for multinational corporations based on home country characteristics (including statutory tax rates, withholding on dividends, CFC provisions, transfer pricing regulations, and foreign tax credits), and empirically test their effect on after-tax expected returns. They find that these tax system characteristics influence

\footnotetext{
${ }^{4}$ Specifically, Huizinga and Voget (2009) estimate the rate of double-taxation as a function of the statutory corporate tax rates of both the parent and subsidiary countries, the withholding rate on dividends paid from the subsidiary country to the parent country, and the parent country's method of providing relief from double-taxation (exemption or foreign tax credit). For example, consider the case of a parent located in a worldwide system with an indirect Foreign Tax Credit with a nonbinding limit (i.e., $\left.t_{j}<t_{i}\right)$. Let $t_{i}\left(t_{j}\right)$ denote the statutory corporate tax rate for the subsidiary (parent) country and $w_{i, j}$ denote the withholding tax rate on dividends paid from the subsidiary country to the parent country. For profits generated in the subsidiary country, the tax rate would equal $t_{i}$. Following an acquisition by a firm in the parent country, profits generated by the subsidiary and repatriated to the parent would be taxed at $t_{i}+\left(1-t_{i}\right) w_{i, j}$ in the subsidiary country. The dividend received by the parent company would be grossed up to its pre-tax value and taxed at $t_{j}$, less the allowed foreign tax credit in the amount of $t_{i}+\left(1-t_{i}\right) w_{i, j}$, resulting in a final effective tax rate for the repatriate foreign profits of $t_{j}$. The resulting rate of double taxation would be the difference in the two countries' statutory corporate tax rates, $t_{j}-t_{i}$. For cases in which the parent is located in a territorial system, the rate of double-taxation is the rate of withholding on dividends, $w_{i, j}$. The authors then apply this rate to the proportion of the combined firm's worldwide pre-tax income that is made up of the income from the subsidiary firm, implicitly assuming that all income of the subsidiary is repatriated to the parent firm.

${ }^{5}$ However, to the extent that relative profitability of the acquiring firm and target firm drive organizational structure, the authors' results could be inappropriately attributed to tax effects using their measure.
} 
multinational firms' after-tax ROA, which suggests that further exploration of the effects of tax system characteristics on cross-border M\&As is warranted. I include statutory corporate income tax rates as a potential determinant of cross-border M\&As but I also examine other major tax system characteristics that determine the tax treatment of foreign-sourced income, including dividend withholding tax rates (determined under existing tax treaties, where relevant), worldwide versus territorial regimes, transfer pricing and thin capitalization regulations, CFC provisions, foreign tax credits and the presence of an IP box regime, allowed in both the target and acquiring firms' countries. I discuss each of these characteristics and their potential implications for cross-border M\&As below.

\section{Differences in Statutory Tax Rates}

Consistent with Erel et al. (2012), I consider the effect of the difference in the acquirer and target countries' statutory corporate income tax rates on cross-border M\&As; however, I expand this analysis by also looking at other factors contributing to the tax costs of repatriating income from a foreign target to the acquirer. Using information on the location of terminal subsidiaries of U.S. multinational firms, along with the use of foreign holding companies, Dyreng, Lindsey, Markle, and Shackelford (2015) find evidence that U.S. multinationals consider the costs of repatriating dividends, as measured by dividend withholding tax rates, in selecting whether to use a foreign holding company, and, if so, where to locate it. I expect that firms will consider withholding tax rates on dividends made between the acquirer and the target as a cost of operating the foreign subsidiary. Therefore, I expect that, all else equal, acquirers will invest in foreign subsidiaries located in countries which have low rates of withholding on dividends. 


\section{Worldwide and Territorial Regimes}

Tax systems are commonly separated into worldwide (credit) or territorial (exemption) systems. In a pure worldwide system, the foreign-sourced income of a domestic firm is effectively taxed at the higher of the domestic tax rate or the foreign tax rate, as foreign-sourced income, including profits of foreign subsidiaries, are includable in domestic taxable income and foreign taxes paid are generally allowed to be credited against domestic tax due on the same income. In this way, a pure worldwide system exhibits capital export neutrality in that resident firms pay the same tax rate for their domestic and foreign income. On the other hand, a pure territorial system exempts all foreign-sourced income from domestic taxation. A pure territorial system exhibits capital import neutrality, as it will result in firms paying the rate of tax in the jurisdiction in which the income is sourced (Richman 1963; Musgrave 1969). In reality, tax jurisdictions are not pure worldwide or pure territorial systems, and thus, exhibit neither capital export neutrality nor import neutrality. Because an acquisition by a firm in a worldwide country subjects the target's income to a second level of taxation in the acquirer country, I expect that firms in territorial regimes more frequently acquire foreign subsidiaries and are net acquirers in cross-border M\&As.

\section{Controlled Foreign Corporation (CFC) Provisions}

Another common tax system characteristic that may impact cross-border M\&A decisions are CFC provisions, which are used to prevent erosion of the domestic tax base. While CFC provisions differ across tax regimes, the defining characteristic of CFC provisions is the immediate inclusion of foreign-source income of a "controlled" foreign subsidiary's income in the parent's domestic taxable income. ${ }^{6}$ In a territorial tax system, CFC provisions disallow the

\footnotetext{
${ }^{6} \mathrm{CFC}$ provisions, such as the definition of control and the types of income that are includable in domestic taxable income, vary across tax regimes.
} 
exclusion of certain foreign-source income; in a worldwide system, CFC provisions disallow the deferral privilege for that income. CFC provisions present an additional tax cost to acquirers, as they cause a loss of deferral when the parent country has a worldwide regime and a loss of exemption when the parent country has a territorial regime. As a result, acquirers in countries without CFC provisions will generate a higher after-tax rate of return from the acquisition of control of a foreign subsidiary. Consistent with this theory, Markle and Robinson (2012) examine the effects of CFC provisions and worldwide versus territorial tax systems on the demand for tax haven operations. They find that the presence and inclusiveness of CFC provisions in the parent firm's country reduce the likelihood that a firm operates a subsidiary in a tax haven country. In a concurrent working paper, Hagen and Prettl (2017) document that, when considering cross-border M\&A that results in control of the target firm, the probability of being an acquirer of a low-tax target is lower when the acquirer is subject to CFC provisions. Because the presence of CFC provisions in the acquirer country likely increase the costs of operating a foreign subsidiary, I expect that acquirers subject to CFC provisions will be less acquisitive, and that, given the opportunity to structure M\&As such that the resulting firm will not be subject to CFC provisions, the acquirer is less likely to have CFC provisions than the target firm.

\section{Transfer Pricing and Thin Capitalization Regulations}

Transfer pricing and thin capitalization regulations are anti-tax avoidance rules aimed at limiting profit shifting via transfer price manipulation and intra-company debt, respectively. Firms may manipulate intra-company transfer prices or intra-company debt to move income from high-tax to low-tax jurisdictions, reducing the firm's overall tax burden. However, tax authorities can limit this behavior with specific rules for the deductibility of intra-company payments. Transfer pricing regulations require that the price of goods or services provided 
between related parties must be determined at arms-length. Consistent with firms considering profit-shifting opportunities in cross-border M\&A decisions, Mescall and Klassen (2014) find that merger premia are reduced as transfer pricing risk from the target firm increases. ${ }^{7}$ Because parent firms can produce large tax savings by manipulating intra-company transactions with a subsidiary (or subsidiaries), the absence of provisions that limit manipulation of intra-company pricing or debt in either the parent or target firms' country (the country with the highest tax burden) will likely decrease the cost of operating a foreign subsidiary. Unlike transfer pricing regulations, which may be difficult for tax authorities to enforce due to the difficulty in defining arms-length values, thin capitalization rules are generally formulaic and, thus, are easier to enforce.

\section{Foreign Tax Credit}

Next, I examine the allowance of foreign tax credits on non-exempt foreign-source income. Generally speaking, relief from double-taxation of foreign income is provided through one of two means: exemption or credit. These methods are roughly considered as equivalents to territorial and worldwide regimes, respectively. However, tax systems rarely operate as a pure exemption or credit system. As a result, even territorial tax systems may offer a foreign tax credit for foreign taxes paid on non-exempt income. For example, the presence of a foreign tax credit could alleviate double-taxation when dividends paid by a foreign subsidiary are not eligible for a dividend participation exemption because the acquirer's ownership in the subsidiary is below the participation threshold or the subsidiary's tax rate is below the threshold

\footnotetext{
${ }^{7}$ Mescall and Klassen (2014) estimate the enforcement, severity, and clarity of transfer pricing rules across 33 countries using survey responses from partners and managers in the transfer pricing divisions of two Big Four accounting firms. In their specification, the authors consider only the transfer pricing risk of the target firm. In my setting, I consider the presence of transfer pricing regulations at either the target or acquirer level. As tax authorities are concerned with income being shifted away from their own jurisdiction, using transfer pricing rules at either the acquirer or target levels avoids making assumptions about the direction in which the post-merger firm would prefer to shift profits.
} 
for exemption in the acquirer country. Because the foreign tax credit across all regimes applies only to non-exempt foreign income, the absence of a foreign tax credit should still impose a cost across both worldwide and territorial regimes. As a result, this variable should be incrementally informative to the worldwide and territorial distinction discussed above. I expect that the presence of a foreign tax credit in the parent country reduces the cost of operating a foreign subsidiary. Therefore, I expect that acquirers in territorial countries that allow a foreign tax credit will be more acquisitive than acquirers in territorial countries that do not allow foreign tax credits.

\section{Intellectual Property Box Regimes}

Finally, I examine the effect of preferential tax treatment of income derived from intellectual property, commonly referred to as an IP Box Regime. To incentivize innovation, tax regulators have instituted rules to reduce the amount of income subject to tax or reduce the tax rate on income derived from qualifying IP. Although not typically considered a primary determinant of the tax treatment of foreign-sourced income, the ease with which IP can be transferred to related parties in low-tax countries to facilitate tax-motivated profit-shifting could influence cross-border M\&A. Predictions on the effects of IP Box regimes are unclear ex-ante. The presence of an IP Box regime in the home country reduces the tax benefits of shifting income derived from qualifying IP to a foreign jurisdiction, which may dampen the cross-border M\&A market in favor of domestic M\&A. This would result in reductions in the volume of cross-border M\&A. However, foreign acquirers in an IP Box regime may also be advantaged over other potential bidders in cross-border M\&A transactions, particularly if the target has high levels of IP income that is currently not tax-preferred. I expect that this effect is limited, however, as many IP Box regimes do not grant tax-advantaged treatment to income derived from 
acquired IP unless the IP is substantially further developed in the post-acquisition period.

Similarly, for acquirers not located in IP Box regimes, firms in IP Box regimes may make attractive targets, as the acquirer may shift IP income to the target in order to participate in the tax-advantaged treatment.

\section{Research Methodology}

Determinants of the Volume of Cross-Border M\&As

I examine the determinants of cross-border M\&As using a regression adapted from Erel et al. (2012). I define two dependent variables, CBMA_Volume and CBMA_Direction, to separately capture the volume of cross-border M\&As that occur between an ordered country pair and the likelihood of being the acquirer country in cross-border M\&A between a specific country pair, respectively. These variables are composed similarly to the dependent variable in Erel et al. (2012), which is calculated by taking the number of cross-border acquisitions of firms in country $i$ (the target country) by firms in country $j$ (the acquirer country) for period $t$, and scaling it by the sum of the total number of cross-border M\&As between the target country and the acquiring country and the total number of domestic mergers in the target country. However, I deviate slightly from that composition in order to separately examine the volume and direction components. CBMA_Volume is calculated as the number of cross-border acquisitions of firms in country $i$ (the target country) by firms in country $j$ (the acquirer country) for period $t$, scaled by the sum of the total number of domestic mergers in the target country and the acquirer country. ${ }^{8,9}$

\footnotetext{
${ }^{8}$ For example, for the Canada-U.S. 2009 observation, this measure is calculated as the number of acquisitions of U.S. targets by Canadian acquirers in 2009, scaled by the sum of the number of domestic mergers in the U.S. and the number of domestic mergers in Canada in 2009.

${ }^{9}$ The approach in Erel et al. (2012) would call for scaling this measure by only the number of domestic M\&A in the target country. I choose to scale, instead, by the sum of the domestic M\&A markets in both countries for two reasons. First, I seek to examine the decision of firms to acquire a foreign target rather than a domestic one. Therefore, the number of available domestic targets is relevant. Second, the measure used in Erel et al. (2012) is
} 
This measure captures the volume of targets in country $i$ acquired by firms in country $j$ relative to the size of the domestic M\&A markets in both countries. CBMA_Direction is calculated as the number of cross-border acquisitions of firms in country $i$ (the target country) by firms in country $j$ (the acquirer country) for period $t$, scaled by the sum of the total number of cross-border M\&As between the target country and the acquiring country. Therefore, this measure captures the proportion of total M\&A between countries $i$ and $j$ in which country $j$ is the acquirer. As a result, this variable is bounded at 0 and 1 and is undefined in cases in which there is no M\&A between a country-pair during the year. In this section, I discuss tests used to determine the effect of tax system characteristics on the volume of cross-border M\&As from both the target and the acquirer perspective; I discuss tests of the direction of cross-border M\&As in the following section.

In order to examine determinants of the volume of cross-border M\&A, I estimate the following model using ordinary least squares regression, where all variables are as defined in Appendix 1:

$$
\begin{aligned}
& \text { CBMA_Volume }=\alpha+\beta_{1} \text { Diff_Trate_CorpIncTaxi,j,t }+\beta_{2} \text { Trate_Dividendsi,j,t }+
\end{aligned}
$$

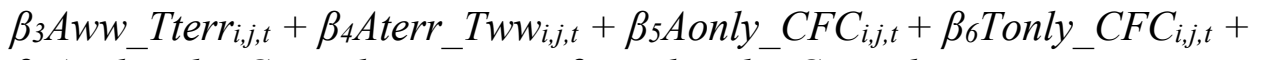

$$
\begin{aligned}
& \beta_{7} \text { Aonly_ThinCapitalization }_{i, j, t}+\beta_{8} \text { Tonly_ThinCapitalization }_{i, j, t}+ \\
& \beta_{9} \text { Aonly_TransferPricing }{ }_{i, j, t}+\beta_{10} \text { Tonly_TransferPricing }{ }_{i, j, t}+\beta_{11} \text { Tonly_FTC }_{i, j, t}
\end{aligned}
$$

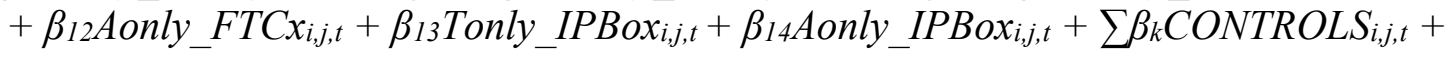

$$
\begin{aligned}
& \sum \beta_{k} A c q F E+\sum \beta_{k} Y e a r F E+\varepsilon
\end{aligned}
$$

In this model, each observation is an ordered country pair, $X_{i, j}$ (where country $i$ denotes the country of the target firm and country $j$ denotes the country of the acquiring firm), such that Canada-Japan and Japan-Canada would be two separate observations.

In order to examine the effects of tax rates on the volume of cross-border M\&As, I first calculate the difference between the acquiring country's and the target country's top statutory tax

highly right-skewed. While skewness in the dependent variable does not violate OLS assumptions, it does limit the usefulness and interpretation of the estimation results. In Appendix 2, I display the results of an OLS estimation of my model using the dependent variable prescribed in Erel et al. (2012). 
rates on corporate income (Diff_Trate_CorpIncTax) ${ }^{10}$ Erel et al. (2012) find that the coefficient on Diff_Trate_CorpIncTax is positive and significant, indicating that firms are more likely to acquire targets in tax jurisdictions with lower corporate income tax rates, consistent with acquirers using cross-border M\&A in order to engage in income-shifting tax avoidance. I expand this analysis by examining the effect of dividend withholding tax rates, as well as other tax system characteristics likely to impact the tax cost of operating a foreign subsidiary.

Withholding tax on dividend payments between the subsidiary and the parent firm represent a cost to repatriating the profits of the target. As such, I expect that acquirers are likely to acquire targets in countries with a lower rate of withholding on dividends. I construct Trate_Dividends as the rate of dividends withholding on dividends paid from the target country to the acquirer country. Because dividend withholding rates are often reduced under the terms of bilateral tax treaties, for country pair year observations with bilateral tax treaties, I replace the general dividend withholding rate with the rate specified under the applicable treaty. Because withholding taxes on repatriation of dividends is an additional cost of operating a foreign subsidiary, I expect that firms engage in more cross-border M\&A when the rate of withholding on dividend repatriation is lower. Therefore, I predict a negative coefficient on Trate_dividends. I also create twelve variables to examine the effects of tax system characteristics that affect the tax base of a multinational firm created by a cross-border M\&A. In this regression, I am interested in exploring how differences in the tax regimes of the target and the acquirer firms may affect the volume of cross-border M\&A between the pair. First, I examine the effect of

\footnotetext{
${ }^{10} \mathrm{I}$ use the difference in the top statutory tax rates following prior literature (Huizinga and Voget 2009; Erel et al. 2012; Feld et al. 2013; Atwood et al. 2015; Col and Errunza 2015) rather than the effective tax rate. I believe this specification to be most appropriate for several reasons. First, firms should base investment decisions on the rate of tax they will pay on their next dollar of income (the marginal tax rate), which is approximated more closely by the statutory rate than the effective tax rate. Second, the effective tax rate is confounded by the tax system characteristics that I examine separately in the model. Finally, a country-level effective tax rate includes the effects of previous foreign investment decisions, including cross-border M\&A decisions.
} 
differences in the tax regime of the firms. Specifically, whether the tax regime of the post-M\&A multinational parent firm will be in a worldwide or territorial regime. To do so, I include two indicator variables. The first one, $A w w_{-}$Tterr, is an indicator variable set equal to one if the acquiring firm is located in a country with a worldwide tax system and the target is located in a country with a territorial tax system, and zero otherwise. ${ }^{11}$ This variable captures M\&As that result in a firm that was taxed under a territorial regime becoming taxed under a worldwide regime as a result of the transaction. The second variable, Aterr_Tww, is an indicator variable set equal to one if the acquiring firm is located in a country with a territorial tax system and the target is located in a country with a worldwide tax system, and zero otherwise. This variable captures M\&As that result in a firm that was taxed under a worldwide regime becoming taxed under a territorial regime. A common criticism of the U.S. worldwide tax system is that it makes U.S. acquirers non-competitive in global markets, one of which is the market for subsidiaries. If this is true, I expect that firms in worldwide countries are less acquisitive, resulting in lower levels of cross-border M\&A, particularly across targets in territorial regimes. Therefore, I expect the coefficient on $A w w \_$Tterr to be negative and the coefficient on Aterr_Tww to be positive, indicating lower (higher) volume of cross-border M\&A between worldwide (territorial) acquirers and territorial (worldwide) targets.

I construct similar indicator variables for the remaining five tax system characteristics. Aonly_CFC (Tonly_CFC) is an indicator variable set to one if only the acquirer (target) country

\footnotetext{
${ }^{11}$ In my setting, a country is designated as territorial if, for subsidiaries that are at least $25 \%$ owned, it allows at least a 95\% participation exemption for foreign dividends paid out of active income. For some countries, the dividend participation exemption only applies when the subsidiary is located in specific countries, such as a tax treaty partner, a country within the European Union or European Economic Area, or countries not blacklisted as tax havens. As a result, I allow a country's designation as worldwide or territorial to differ across country pairs. My results are qualitatively and quantitatively similar when I designate a country as territorial without regard to specific country pairs. In this case, a country is designated as territorial if it allows at least a 95\% participation exemption for foreign dividends paid by a subsidiary that is at least $25 \%$ owned when the subsidiary is located in a treaty country or a country that is not blacklisted as a tax haven.
} 
has $\mathrm{CFC}$ provisions, and zero otherwise. Because the presence of $\mathrm{CFC}$ provisions in the acquirer country may make the profits of the foreign subsidiary taxable in the acquirer country, I expect that acquirers subject to CFC provisions are disadvantaged in cross-border M\&A transactions. Thus, I expect the coefficient on Aonly_CFC to be negative, reflecting a reduction in the volume of cross-border M\&A when the acquirer country is located in a $\mathrm{CFC}$ regime and the target is not.

Both thin capitalization rules and transfer pricing regulations limit the extent to which firms can shift profits to tax-preferred jurisdictions. Because these regulations limit firms' tax avoidance strategies through profit-shifting channels, I expect that the presence of these regulations will reduce the volume of cross-border M\&A. However, it is unclear whether the effect will be from the presence of regulation at the acquirer level or target level, as the direction in which the post-merger firm will wish to shift income is unclear, and tax regulators are concerned with income being shifted away from their own jurisdiction. If post-merger firms, on average, prefer to shift income to the target (which is consistent with acquirer firms, on average, having a higher corporate income tax rate), I expect the coefficients on Aonly_ThinCapitalization (Tonly_ThinCapitalization) and Aonly_TransferPricing (Tonly_TransferPricing) to be negative (positive).

Next, Aonly_FTC (Tonly_FTC) are indicator variables set to one if only the acquirer (target) country allows for a foreign tax credit to provide relief from double-taxation of foreign income, and zero otherwise. For non-exempt foreign income, double taxation relief is generally provided by a tax credit or a tax deduction. Because a foreign tax credit should reduce or eliminate the double-taxation of non-exempt foreign profits, I expect that firms allowed a foreign tax credit will engage in higher levels of cross-border M\&A, as they will be able to operate 
foreign subsidiaries at a lower cost. Therefore, I expect the coefficient on Aonly_FTC to be positive and the coefficient on Tonly_FTC to be negative.

Finally, Aonly_IPBox (Tonly_IPBox) is an indicator variable set equal to one if only the acquirer (target) country is an IP Box regime. However, it is difficult to make predictions regarding the effect of IP box regimes on the volume of cross-border M\&A. Because intellectual property is among the assets easiest to transfer to tax-preferred jurisdictions, firms in countries without preferable tax treatment of intellectual property income may engage in more crossborder M\&A to facilitate shifting intellectual property to another tax jurisdiction, particularly jurisdictions that do provide tax-preferred treatment of income from IP. This would result in reductions in the volume of cross-border M\&A. In this case, I predict a negative coefficient on Aonly_IPBox. For acquirers not in IP Box regimes, the acquisition of a target in an IP Box regime may allow the acquirer to shift qualifying IP income to the target, which suggests a positive coefficient on Tonly_IPBox. However, if the presence of an IP Box regime in their country provides an advantage to foreign acquirers, particularly in acquisitions of targets with high levels of IP income that is currently not tax-preferred, I predict a positive coefficient on Aonly_IPBox. Because many IP Box regimes do not grant tax-advantaged treatment to income derived from acquired IP unless the IP is substantially further developed in the post-acquisition period, this effect may be limited.

I also control for other determinants of cross-border M\&As using variables from Erel et al. (2012). I control for valuation differences by including diff_xrate equal to the difference between the real annual currency exchange rate return between the two countries' currencies and diff_realri the difference in the real annual stock market return of the country indices. I control for disclosure quality using diff_disclosureindex, the difference between the two countries' 
ratings on the "extent to which investors are protected through disclosure of... financial information" from the WorldBank Doing Business survey. I also control for the legal protection of minority shareholders using the difference between both country's value for the anti-selfdealing index from Djankov, La Porta, Lopez-de-Silanes, and Shleifer (2008) (diff_anti_selfdeal). To control for language (cultural) barriers, I include an indicator variable equal to one if the two countries have the same primary language (religion), and zero otherwise. To control for geographic proximity, I include the great circle distance between the capital cities of the acquirer and target countries, scaled by 1,000 for ease of interpretation, $($ gcdist $) .{ }^{12}$ I also control for the volume of business between the two countries using max_trade, the maximum bilateral imports or exports, where imports (exports) are measured as the total proportion of the target country's imports (exports) from (to) the acquirer country. Finally, I control for macroeconomic effects by including diff_gdp, the difference between the natural log of the countries' GDP per capita in 2010 U.S. dollars, and diff_gdpgrowth, the difference in the real annual growth rate in GDP per capita. Following Erel et al. (2012), I include acquirer country fixed effects because I am primarily interested in examining the effects of differences in tax characteristics between the acquirer and target countries on cross-border M\&As between a country-pair. ${ }^{13}$ I also include year fixed effects to control for trends in cross-border M\&A over time.

\footnotetext{
${ }^{12}$ Great circle distance is the shortest distance between two points on the surface of a sphere, and is calculated as $3963.0 * \operatorname{arcos}[\sin ($ lat 1$) * \sin ($ lat 2$)+\cos ($ lat 1$) * \cos (\operatorname{lon} 2-\operatorname{lon} 1)]$, where lon1 (lon2) and lat1 (lat2) are the longitudes and latitudes of the capital city of the acquirer (target) country, respectively.

${ }^{13}$ In untabulated analysis, I replicate my primary findings without the inclusion of acquirer country fixed effects, and the results are qualitatively similar for the effect of tax system characteristics on the direction of cross-border M\&A. For the volume of cross-border M\&A, I confirm the results in Table 3, but I also find evidence that the volume of cross-border M\&A is diminished among worldwide acquirers and territorial targets and in cases in which only the target country allows foreign tax credits, consistent with expectation. I further find that the volume of cross-border M\&A is decreased (increased) when only the target country has thin capitalization requirements (only the acquirer country is an IP Box regime). Predictions for these characteristics were less clear, but my results are consistent with firms preferring to shift income to the target through the use of intercompany debt and IP Box
} 
do this because these tests examine the effect of taxes on the decision to structure the M\&A, not whether to engage in M\&A. The decision regarding which firm will be the acquirer in a crossborder M\&A transaction should be influenced by the difference between the applicable rates, rather than the level.

All controls from Model (1) are included in Model (2) with the exception of three nondirectional variables, geographic distance and the two indicator variables equal to one if the countries have the same primary language or religion, which I remove as non-directional variables should not explain the direction of cross-border M\&A.

First, as above, I examine the effect of differences in the statutory corporate tax rate and the acquirer and target's tax regimes. Consistent with the finding in Erel et al. (2012), I predict a positive coefficient on Diff_Trate_CorpIncTax, indicating that the acquiring firm is, on average, subject to a higher corporate tax rate than the target. Further, I predict a negative coefficient on Diff_Trate_Dividends, indicating that firms structure the M\&A to minimize the withholding tax due on repatriations of income from the target to the acquirer.

Next, I examine the effect of tax regime on the direction of cross-border M\&A. As acquirers located in worldwide tax regimes bring the income of the target under the umbrella of a worldwide regime, subjecting it to taxation at the acquirer level, I expect that, when firms from countries with different tax regimes engage in cross-border M\&A, the acquirer is more likely to be from a territorial regime, while the target is more likely to be from a worldwide regime. This is consistent with firms structuring M\&A in order to avoid bringing the income of a territorial firm under the umbrella of a worldwide tax system. Because I expect that firms in territorial regimes are more likely to acquire, while firms in worldwide regimes are more likely to be targeted, I predict a negative (positive) coefficient on Aww_Tterr (Aterr_Tww). 
Because the presence of CFC provisions in the acquirer country may result in additional taxes due on the income of the target, I expect that when only one country in a cross-border M\&A transaction has CFC provisions, the M\&A is likely to be structured in such a way as to avoid the applicability of the CFC provisions. Therefore, I predict the acquiring firm will be less likely to be subject to CFC rules, suggesting a negative (positive) coefficient on Aonly_CFC (Tonly_CFC).

Thin capitalization rules and transfer pricing regulations both limit tax avoidance through the profit shifting channel. However, because the direction in which the post-merger firm will wish to shift income is not clear, it is difficult to make predictions regarding the effect of these provisions on the direction of cross-border M\&A. If post-merger firms, on average, prefer to shift income to the target (which is consistent with acquirer firms, on average, having a higher corporate income tax rate), I expect the coefficients on Aonly_ThinCapitalization (Tonly_ThinCapitalization) and Aonly_TransferPricing (Tonly_TransferPricing) to be negative (positive).

The presence of a foreign tax credit in the acquirer's jurisdiction can mitigate the effect of paying taxes on the target's income in both the target and the acquirer's jurisdictions. Therefore, I expect that, when only one country involved in a cross-border M\&A allows a foreign tax credit, the acquiring firm is likely to be allowed the credit. Therefore, I expect a positive (negative) coefficient on Aonly_FTC (Tonly_FTC).

Finally, I examine the effect of IP Box regimes on the direction of cross-border M\&A. As with the effect of IP Box regimes on the volume of cross-border M\&A, predictions regarding the effect on the direction of cross-border M\&A are difficult. It is possible that the presence of an IP Box regime in their country provides an advantage to foreign acquirers, particularly in 
acquisitions of targets with high levels of IP income that is currently not tax-preferred, which would suggest a positive coefficient on Aonly_IPBox. However, because many IP Box regimes do not extend tax-preferred treatment to acquired intellectual property unless it is substantially further developed in the post-merger period, it may be that IP Box regimes do not have any effect on the direction of cross-border M\&A.

\section{Determinants by Acquirer Tax Regime}

I further expect that the tax system characteristics may have different implications for cross-border M\&As when the acquiring firm is taxed under a worldwide or territorial regime, as many of these tax system characteristics will generate different tax effects under each regime. For example, in a worldwide tax system, CFC provisions prevent the deferral of the recognition of taxable income that otherwise would have been taxed upon repatriation. However, in a territorial tax system, CFC provisions require the inclusion of income that would not otherwise be subjected to tax in the acquirer country at all. Similarly, transfer pricing regulations may be more costly for parent firms located in territorial tax systems. When a firm in a territorial tax system is able to shift income to a foreign subsidiary in a tax-preferred jurisdiction, the income is never subject to tax by the parent country. However, in a pure worldwide system, shifting income does not produce permanent tax avoidance, but tax deferral. ${ }^{14}$ Consistent with this, Markle (2016) finds that firms in territorial tax regimes engage in more profit shifting than firms in worldwide systems.

Because theory suggests that the effect of these characteristics may vary with the acquiring firm's tax regime, I also estimate the effect of these characteristics separately for

\footnotetext{
${ }^{14}$ In countries with a worldwide system that allows worldwide averaging (all foreign income and all foreign tax is pooled) for purposes of calculating a foreign tax credit limitation (generally referred to as "cross-crediting"), profit shifting could lead to tax avoidance through manipulation of the foreign tax credit limitation if the limitation was binding.
} 
acquiring countries in worldwide regimes and acquiring countries in territorial regimes to determine if the impact of these tax system characteristics on cross-border M\&As differs across acquirer regime. Specifically, I estimate this regression separately for the acquirer countries in a worldwide system and those in a territorial system by modifying regression model (1) to eliminate the variables $A w w_{-}$Tterr and Aterr_Tww, and replace that with an indicator variable, $T \_w w$, equal to one if the target country is a worldwide tax regime, and zero otherwise. I use Seemingly Unrelated Regression and conduct t-tests of differences in coefficients across the two subsamples.

\section{Data Sources and Sample Construction}

I construct my sample of M\&As using Security Data Corporation's (SDC) Mergers and Corporate Transactions database. I collect all M\&As announced between January 1, 2006 and December 31, 2015, inclusive. Following Erel et al. (2012), I exclude leveraged buyouts, spinoffs, recapitalizations, self-tender offers, exchange offers, repurchases, and privatizations, and I eliminate deals in which either the target or acquirer is a government agency or in the financial or utilities industries. ${ }^{15}$ In my final sample, I consider M\&A transactions from 50 countries for which I have all necessary control variables, which covers 62,614 total cross-border M\&A transactions. Because each observation is an ordered country pair year and I have 50 countries in my sample, the total number of observations theoretically available is $24,500(50 \times 49 \times 10)$.

\footnotetext{
${ }^{15}$ In untabulated analysis, I re-estimate my analyses on two additional samples. First, I expand the sample to consider M\&A not completed. Next, I further restrict my main sample to cross-border M\&A in which the target is more than $50 \%$ owned following the M\&A transaction and the ultimate acquirer is located in the same country as the immediate acquirer following sensitivity tests in Huizinga and Voget (2009) and main analyses in Hagen and Prettl (2017). My results remain quantitatively and qualitatively similar across all three samples.
} 
However, due to missing data or an undefined dependent variable, the number of observations drops to 21,754 for my primary volume analysis and 10,454 for my primary direction analysis. ${ }^{16}$

My variables of interest are tax rates and tax system characteristics hand-collected from Ernst \& Young Worldwide Corporate Tax Guides (2004-2015) and the PwC Worldwide Tax Summaries (2010/2011-2015/2016). This allows me to take advantage of changes in tax regimes across time. From SDC, I collect the announcement date, the fraction of the target firms owned by the acquirer following the acquisition, and primary industry as indicated by the Standard Industrial Classification (SIC) code, and country of domicile ${ }^{17}$, along with the completion date where applicable, and deal value (in U.S. dollar terms) where available.

Country-level variables are collected from multiple sources. I collect primary language and primary religion from the FBI World Factbook. I obtain the latitude and longitude of the capital cities of each country from WorldData (www.worlddata.info). Bilateral trade data is collected from the United Nations Commodity Trade Statistics Database. Gross domestic product (GDP) per capita and GDP per capita growth rates are collected from the WorldBank National Accounts data. I collect the 2010 consumer price index (CPI) from the International Monetary Fund through WorldBank. I measure the quality of accounting disclosure using the disclosure index from the WorldBank Doing Business Project. The anti-self-dealing index, a measure of protections for minority shareholders, is from Djankov et al. (2008). Institutional quality is collected from the International Country Risk Guide (ICRG) published by the Political Risk Services group following Bekaert, Harvey, and Luncblad (2005). Investment profile is also

\footnotetext{
${ }^{16}$ A value for CBMA_Direction will be undefined if no cross-border M\&As occurred between countries $i$ and $j$ during the year.

${ }^{17}$ Per SDC, the country of domicile is the location of the firm's headquarters and/or operations.
} 
collected from the ICRG. I collect nominal bilateral exchanges rates and total value-weighted return indices from Datastream.

\section{Primary Results}

Descriptive Statistics

Table 1 displays the 50 countries included in my analysis, along with the pattern of crossborder and domestic M\&As over my entire sample period. Each row contains a target country, and each column contains an acquirer country, such that the diagonal entries contain the number of domestic M\&As that occurred in a country over my sample period. The off-diagonal entries represent the number of cross-border M\&As that occurred for each ordered country pair. In terms of the raw number of cross-border M\&As, the United States (Kenya) is both the most (least) common acquirer and the most (least) commonly targeted in cross-border M\&As during my sample period. When the number of cross-border M\&As is scaled by the size of the domestic M\&A market, firms in Luxembourg are most likely to be acquirers and targets in crossborder M\&As, while firms in Russia (Japan) are least likely to be acquirers (targets).

\section{INSERT TABLE 1 HERE}

In Table 2, I present descriptive statistics for my sample of ordered country pair years. By construction, the mean difference in corporate income tax rates is near zero, as the use of ordered country pair observations creates off-setting values. Differences in dividend tax rates, however, are asymmetrical, as the tax rate paid on dividends from country $i$ to country $j$ may not equal the tax rate paid on dividends from country $j$ to country $i$. My descriptive statistics suggest that in about half of country pairs, both the target and the acquirer operate in either a territorial or worldwide regime, leaving about a quarter of country pairs in which only the acquirer country is 
located in a worldwide regime and a quarter of country pairs in which only the target country is located in a worldwide regime. CFC provisions and thin capitalization rules occur similarly in my sample. Transfer pricing and the allowance of a foreign tax credit are far more common, leaving a smaller number of ordered country pair year observations in which one country does not exhibit the tax system characteristic. IP Box regimes are relatively uncommon, producing a similar result.

\section{INSERT TABLE 2 HERE}

\section{Determinants of the Volume of Cross-Border $M \& A$}

The results of the estimation of model (1) are presented in Table 3 Panel A. Across known determinants of the volume of cross-border M\&As, my results are largely consistent with prior literature. Consistent with Erel et al. (2012), I find that geographic distance, existing trade, shared language, and cultural similarity (measured using shared primary religion) are important determinants of the volume of cross-border M\&A. Specifically, I find that the volume of crossborder M\&A between a country-pair is higher when the countries share a language, share a religion, are sizeable trading partners, and are close to each other (GCDist is smaller). I also find that the volume of cross-border M\&A is lower when Diff_GDPgrowth is higher. A higher value for Diff_GDPgrowth indicates that the target country's GDP growth is higher than the acquirer country's GDP growth. Thus, this result indicates that the volume of cross-border M\&A is higher between acquirer countries with lower GDP growth than their target countries, suggesting that firms increase cross-border M\&A to invest in higher-growth countries. I also find evidence that the volume of cross-border M\&As is higher among country pairs in which the target has better disclosure quality than the acquirer (Diff_DisclosureIndex is lower); this finding is not consistent with the results in Erel et al. (2012), though I use a different measure of disclosure in 
my model. Unlike Erel et al. (2012), however, I do not find that firms increase cross-border M\&A in order to exploit valuation effects caused by currency exchange rate or stock market returns.

\section{INSERT TABLE 3, PANEL A HERE}

Similar to Erel et al. (2012), I find that acquirers more frequently acquire targets in countries with lower statutory income tax rates. In addition to examining statutory corporate tax rates, I expand Erel et al. (2012) to examine the effect of dividend withholding rates. My results suggest that the volume of cross-border M\&A increases when the cost of repatriating dividends from the target the acquirer country is lower.

Of the tax system characteristics that I examine, I find that CFC provisions and transfer pricing regulations are significant determinants of cross-border M\&A. Consistent with predictions, my results suggest that the presence of CFC provisions in the acquirer country reduces the volume of cross-border M\&As. The significantly negative coefficient on Aonly_TP suggests that transfer pricing regulations also reduce the returns to cross-border $\mathrm{M} \& \mathrm{~A}$, consistent with these regulations preventing or curtailing the use of profit-shifting for tax avoidance. This result is consistent with the post-merger firm, on average, preferring to shift taxable income from the acquirer to the target. Though the coefficients are directionally consistent with firms in territorial systems being advantaged in cross-border M\&As compared to worldwide tax systems, the coefficients are insignificant. I also do not find that thin capitalization rules, foreign tax credits, or IP Box regimes are significant determinants of the volume of M\&A.

In Table 3, Panel B, I examine each tax system characteristic independently, and I find my results are largely consistent across these specifications. Again, I find that the presence of CFC provisions and transfer pricing regulations in the acquirer country or high rates of dividend 
withholding reduce the volume of cross-border M\&A. However, I find that the coefficient on Diff_Trate_CorpIncTax, while positive in all specifications, is only significant in two of the six specifications. Further, I find that, though the effect is subsumed by the effect of other tax system characteristics, the coefficient on auponly_ipbox is negative and significant, suggesting that firms located in tax jurisdictions that allow for tax-preferenced treatment of IP income are less likely to acquire foreign targets. I interpret this as weak evidence that IP box regimes may successfully reduce firms' incentives to shift income.

\section{INSERT TABLE 3, PANEL B HERE}

\section{Determinants of Volume by Acquirer Tax Regime}

Next, I present the results of my estimation of model (1) separately for acquirers based in worldwide and territorial regimes in Table 4. In the analysis above, I make determinations of worldwide and territorial regimes at the country pair year level. However, to compare the way these tax system characteristics impact M\&As across tax regimes, I indicate an acquirer country as worldwide or territorial without consideration for the specific target country in this anlaysis. A country is indicated as worldwide or territorial based on the general tax treatment for countries under a bilateral tax treaty. Countries that only allow dividend participation exemptions under the European Union Parent-Subsidiary Directive of 1990 are not considered to be generally territorial. ${ }^{18}$ In this analysis, I continue to find evidence that CFC provisions and transfer pricing regulations in the acquirer country reduce the volume of cross-border M\&A across both worldwide and territorial regimes. However, I do not find evidence that any of these tax system characteristics have differential effects on the volume of cross-border M\&A based on the acquirer tax regime.

\footnotetext{
${ }^{18}$ Results are qualitatively and quantitatively similar if I allow the acquirer country's regime designation to change with each country pair, as it does in the primary analysis.
} 


\section{INSERT TABLE 4 HERE}

Determinants of the Direction of Cross-Border $M \& A$

Next, I examine the effect of tax system characteristics on the direction of cross-border M\&A. That is, given that an M\&A occurs between firms located in two countries, I examine which country is more likely to be the domicile of the acquiring firm. I present the results of my estimation of Model (2) in Table 5.

\section{INSERT TABLE 5, PANEL A HERE}

In Table 5, Panel A, I again find strong evidence that tax rates influence cross-border M\&A decisions. Consistent with the findings in Erel et al. (2012), I find that the acquirer is likely to have a higher rate of tax on corporate income than the target firm, indicated by a positive coefficient on Diff_trate_Corpinctax. Further, I document a significantly negative coefficient on Diff_Trate_Dividends. This provides evidence that firms select the direction of the M\&A that minimizes the cost of withholding tax on dividends paid between the two countries. I also find a significantly negative coefficient on $A w w_{-}$Tterr, indicating that crossborder M\&A between an acquirer in a worldwide regime and a target in a territorial regime is less common than cross-border M\&A between an acquirer in a territorial regime and a target in a worldwide regime or between a target and acquirer in the same type of tax regime. This indicates that cross-border M\&As are less likely to be structured in such a way that a target in a territorial system is put under the umbrella of a worldwide regime.

My results indicate that CFC provisions and thin capitalization rules have the largest influence on the direction of cross-border M\&A. I find that cross-border M\&As are positively (negatively) associated with the target (acquirer) alone being subject to CFC provisions. This is consistent with firms structuring cross-border M\&As so as to avoid the adverse tax consequences 
of the target being classified as a controlled foreign corporation. The size and significance of the coefficients on CFC provisions suggests that the presence of CFC provisions is a more important factor in determining the direction of cross-border M\&A than whether the acquirer is in a worldwide or territorial regime. I suggest that this could be due to the deferral privilege available in many worldwide regimes. This privilege allows firms to defer paying the additional layer of tax until the profits of the target are repatriated to the acquirer country. This privilege can be used to avoid the taxes indefinitely, provided that the acquirer continues to invest the profits of the target in foreign assets.

I also find evidence that cross-border M\&As are positively (negatively) associated with the acquirer (target) being subject to thin capitalization rules when the target (acquirer) is not subject to these rules. This result is consistent with post-merger firms preferring to shift income from the acquirer to the target through the use of inter-company debt. However, I also find a positive and significant coefficient on Aonly_TP.

Finally, I find a positive and significant coefficient on Aonly_FTC, suggesting that M\&A is generally structured such that the acquirer can claim a foreign tax credit on taxes paid to foreign jurisdictions on income that is also subject to tax in the home country. I do not find evidence that firms consider the presence of an IP box regime to influence the direction of crossborder M\&A.

In Table 5 Panel B, I allow each tax system characteristic to enter the regression independently. My results on corporate income tax rates, dividend withholding rates, CFC provisions and thin capitalization rules are virtually unchanged, but I do not find that tax regime (worldwide or territorial) significantly explains the direction of M\&A in this specification. Interestingly, I find that the coefficient on Aonly_FTC, which was significantly positive in Panel 
A, becomes significantly negative in this specification. It is possible that, without controlling for the acquirer and target countries' tax regime, the presence of a foreign tax credit is acting as a proxy for a worldwide tax regime.

\section{INSERT TABLE 5, PANEL B HERE}

\section{Determinants of Direction by Acquirer Tax Regime}

In Table 6, I separately estimate the regression for the sample of acquirers in worldwide regimes and acquirers in territorial regimes.

\section{INSERT TABLE 6 HERE}

My results are largely consistent across both regimes, suggesting that my findings in Table 5 are not driven by only one tax regime. However, I do find that the coefficient on Tonly_FTC to be positive and significant for acquirers in worldwide regimes, but negative and significant for acquirers in territorial regimes. In a territorial regime, the presence of a foreign tax credit affects the direction of cross-border M\&A in a way that is consistent with predictions. Specifically, the direction of cross-border M\&A favors acquirers that are granted a foreign tax credit when only one of the countries allows it. The results in a worldwide regime, however, are surprising. I find a strong positive coefficient on Tonly_FTC that exceeds the positive and significant coefficient on Aonly_FTC. Note that if the acquirer is in a worldwide regime but only the target country allows a foreign tax credit, the acquirer taxes worldwide income, but does not allow a general double-tax relief provision. In these rare occurrences, the countries provide relief from double-taxation only through the presence of existing tax treaties, which themselves may grant foreign tax credits. Because I do not consult treaty provisions in defining any tax system characteristics other than dividend withholding rates, my sample contains a small number 
of countries in worldwide regimes that do not grant a general foreign tax credit. I note that this strange result is driven by a small number of countries.

\section{Supplemental Tests}

\section{Country-Level Analysis}

In my main tests, I use a sample of ordered country pair years to examine the effect of differences in tax system characteristics between the countries of the acquirer and the target firms in the volume and direction of cross-border M\&A between the two countries. To supplement these findings, I present similar tests on a sample of country-year observations. Because I do not use country-pair observations, I do not exploit differences in tax system characteristics across the two countries involved in a cross-border M\&A. Rather, I examine whether the presence of these tax system characteristics has an effect on the volume or direction of the country's global M\&A investments. In this specification, I separately examine the volume of cross-border M\&A from a target perspective and an acquirer perspective. In examining the target perspective, I determine the effect of tax system characteristics on the likelihood of being a target in a cross-border M\&A relative to being targeted domestically. Similarly, the acquirer perspective examines the effect of tax system characteristics on the likelihood of being an acquirer in a cross-border M\&A relative to acquiring domestically. Finally, I examine the effect of tax system characteristics on the direction of global M\&A. That is, considering all cross-border M\&A, I examine the likelihood that a country is a net global acquirer or a net global target.

I specify a new model to examine these country-level tax system characteristics. Specifically, I estimate the following model using ordinary least squares regression where all variables are as defined in Appendix A: 


$$
\begin{aligned}
& C L=\alpha+\beta_{1} \text { Trate_CorpIncTax } x_{x,-1}+\beta_{2} W_{x, t-1}+\beta_{3} C_{F C} C_{x, t-1}+ \\
& \beta_{4} \text { ThinCapitalization } x_{x, t-1}+\beta_{5} \text { TransferPricing } x, t-1+\beta_{6} F T C_{x, t-1}+\beta_{7} \text { IPBox }_{x, t-1}+ \\
& \sum \beta_{k} \text { CONTROLS } S_{x, t-1}+\sum \beta_{k} \text { YearFE }+\varepsilon
\end{aligned}
$$

In this model, each observation is a country year, where $x$ denotes country and $t$ denotes year. My dependent variables, $C L \_T$ Tolume (CL_AVolume) and $C L \_$Direction, capture the total number of firms in country $x$ targeted by foreign firms (the total number of foreign firms acquired by firms in country $x$ ) relative to firms targeted domestically, and the proportion of total cross-border M\&A in which the country is the acquirer, respectively. CL_TVolume (CL_AVolume) is calculated as the number of cross-border acquisitions of targets in country $x$ by acquirers in all foreign countries (the total number of acquisitions by firms in country $x$ of targets in all countries excluding country $x$ ) for period $t$, scaled by the total number of domestic mergers in country $x$. This measure captures the volume of targets in country $x$ acquired by foreign firms relative to those acquired by domestic firms. CL_Direction is the proportion of cross-border M\&A involving country $x$ in which country $x$ is the acquirer, and is calculated as the number of cross-border acquisitions in which the acquiring firm is in country $x$ for period $t$, scaled by the sum of the total number of cross-border M\&As in which either the acquiring firm or the targeted firm is in country $x$. Therefore, a value greater than .5 indicates that the country is a net acquirer in cross-border M\&A, while a value less than .5 indicates the country is a net target. Because dividend withholding rates vary greatly depending upon the partner country and cannot be reliably determined on a country level, I do not include dividend withholding rates in this model. Trate_CorpIncTax is defined as the top statutory tax rate on corporate income. All other tax system characteristics are indicator variables equal to one if the characteristic is present in country $x$ for period $t$, and zero otherwise. 
My sample for these analyses are country-year observations. Because I have a sample of 50 countries over 10 years, I have a possible 500 total observations $(50 \times 10)$. However, I lose 31 observations due to missing data, leaving me with 469 total observations. I present descriptive statistics for this sample in Table 7.

\section{INSERT TABLE 7 HERE}

In my sample, the median top statutory tax rate is $25 \%$, and my sample is almost evenly divided on CFC provisions, thin capitalization rules, and worldwide tax regime. Transfer pricing regulations and foreign tax credits are far more common, while only $13.6 \%$ of countries have IP Box regimes.

I present the results of my estimation of Model (3) in Tables 8 and 9. I first examine the effect of these characteristics on the volume of cross-border M\&A in Table 8. In Table 8, Panel A, I examine the target perspective. In Table 8 , Panel B, I examine the acquirer's perspective.

\section{INSERT TABLE 8, PANEL A HERE}

In Table 8, Panel A, I adopt the target perspective and examine the effect of tax system characteristics on the likelihood of being targeted by a foreign firm. The negative and significant coefficient on Trate_CorpIncTax indicates that countries with high corporate income tax rates are less likely to be acquired by a foreign firm relative to the size of their domestic M\&A market. This is consistent with my findings in Table 3, which indicates that, in cross-border M\&A, the acquiring firm is generally subjected to a higher tax rate than the target firm. I find a similar results for the presence of a foreign tax credit, indicating that firms that allowed a foreign tax credit are less likely to be acquired in cross-border M\&A. The coefficient on IPBox is positive and significant, indicating that the presence of an IP Box regime makes a firm more likely to be acquired by a foreign firm. This could indicate that cross-border M\&A facilitates shifting IP to 
jurisdictions with favorable tax treatment of IP income. Notably, the positive coefficient on WW is narrowly insignificant (significant in a one-tailed test). A positive and significant coefficient on this variable would indicate that the presence of a worldwide regime increases the volume of takeovers by foreign firms relative to domestic takeovers, which is consistent with arguments that the U.S. worldwide tax system may make U.S. firms more valuable in the hands of a foreign parent.

\section{INSERT TABLE 8, PANEL B}

In Table 8, Panel B, I examine the acquirer's perspective. In this analysis, I find a negative and significant coefficient on $C F C$. I interpret this as additional support for my finding in Table 3, which suggests that the presence of CFC provisions in the acquirer country decrease the volume of cross-border M\&A.

\section{INSERT TABLE 9 HERE}

In Table 9, I examine the effect of these tax system characteristics on the direction of cross-border M\&A for a country. That is, considering all cross-border M\&A in which a firm in the country is a participant, in what proportion is the country acquiring a foreign target rather than being acquired by a foreign firm? I find that statutory tax rate, CFC provisions, and thin capitalization provisions are determinants of the direction of cross-border M\&A, consistent with the results in Table 5. Specifically, I find that having a high corporate tax rate makes a country more likely to be a net acquirer, while the presence of CFC provisions and thin capitalization rules reduce the likelihood that a country will be a net acquirer.

\section{Additional Analysis}


My primary analyses provide insight into the determinants of the volume and direction of cross-border M\&As. However, tax system characteristics are also likely to be considerations in other decisions regarding the structure of cross-border M\&A. For these analyses, I use the same sample used in Tables 3 through 6, though my sample size is reduced by the number of ordered country pair year observations that do not have at least one completed cross-border M\&A during the year. ${ }^{19}$

\section{Obtaining Control in Cross-Border $M \& A$}

First, I consider the effect of tax system characteristics on the likelihood of the acquirer obtaining control (which I define as greater than or equal to $50 \%$ ownership) of the target. While all of the M\&A transactions in my sample represent a substantial investment in the target, obtaining control of the target will trigger the effect of CFC provisions, if applicable, though it may also make tax avoidance strategies, such as profit shifting, more likely. To examine the effect of tax system characteristics on the likelihood of obtaining control of a foreign target, I construct CBMA_Control as the total number of cross-border acquisitions of firms in country $i$ by firms in country $j$ for period $t$ in which the acquirer owns over 50 percent of the target following the transaction, and scaling it by total number of cross-border acquisitions of firms in country $i$ by firms in country $j$ for period $t$. I present the results in Table 10. As predicted, CFC provisions are highly important in determining the likelihood of a firm obtaining control of the target in a cross-border M\&A. Consistent with expectations, the proportion of cross-border M\&A that result in a controlled subsidiary is significantly lower (higher) when the acquirer (target) alone is subject to $\mathrm{CFC}$ provisions. The M\&A is also more likely to result in a

\footnotetext{
${ }^{19}$ A value for CBMA_intermediary and CBMA_Control will be undefined if no cross-border M\&A occurred in which country $i$ was the acquirer and country $j$ was the target during the year.
} 
controlled target when the acquirer has a higher corporate tax rate, benefits from the allowance of a foreign tax credit, and is not subject to thin capitalization rules.

\section{INSERT TABLE 10 HERE}

\section{Use of an Intermediary Country in Cross-Border M\&A}

Next, I consider the use of an immediate acquirer in a country that is neither country $i$ nor country $j$, as the total proportion of cross-border M\&As in which the acquisition was facilitated through a direct acquirer located in a third country, I construct CBMA_Intermediary as the total number of cross-border acquisitions of firms in country $i$ by firms in country $j$ through a direct acquirer located in a country that is neither country $i$ nor country $j$ for period $t$, and scaling it by total number of cross-border acquisitions of firms in country $i$ by firms in country $j$ for period $t$. Table 11 presents the results.

\section{INSERT TABLE 11 HERE}

I find that, when the target is located in a worldwide regime and the acquirer is located in a territorial regime, the cross-border M\&A is less likely to include an intermediary in a third country. As bringing a firm from a territorial regime under the umbrella of a worldwide regime is costly, it is possible that firms in worldwide regimes are more likely to own territorial firms through another country. In this way, the post-merger multinational firm could use an intermediary country to facilitate the flow of capital between subsidiaries without repatriating income from the territorial subsidiary to the worldwide parent firm. In addition, I find that firms are less likely to use an intermediary country when only the acquirer is subject to thin capitalization rules. 


\section{Tax System Characteristics and Merger Premia}

In addition to examining the volume, direction, and structure of cross-border M\&A, I next examine the effect of tax system characteristics on the merger premia in cross-border M\&A. In these tests, I eliminate cross-border M\&A transactions for which the four-week merger premium is unavailable in SDC, leaving me with only 1,518 observations.

$$
\begin{aligned}
& \text { Premia }=\alpha+\beta_{1} \text { Diff Trate CorpIncTax } x_{i, j, t-1}+\beta_{2} \text { Diff Trate Dividends } i_{i, j-1}+
\end{aligned}
$$

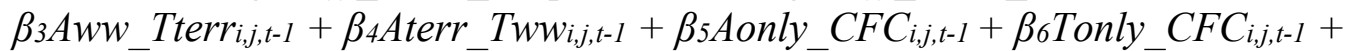

$$
\begin{aligned}
& \beta_{7} \text { Aonly_ThinCapitalization }_{i, j, t-1}+\beta_{8} \text { Tonly_ThinCapitalization }_{i, j, t-1}+ \\
& \beta_{9} \text { Aonly_TransferPricing }_{i, j, t-1}+\beta_{10 \text { Tonly_TransferPricing }}{ }_{i, j, t-1}+ \\
& \beta_{11} \text { Tonly_FTC } \text { i,j,t-1 }_{1}+\beta_{12} \text { Aonly_FTCx }_{i, j, t-1}+\beta_{13} \text { Tonly_IPBox }_{i, j, t-1}+\beta_{14} \text { Aonly_IPBox }_{i, j, t-1}+ \\
& \sum \beta_{k} \text { CONTROLS } S_{i, j, t-1}+\sum \beta_{k} A c q F E+\sum \beta_{k} Y e a r F E+\varepsilon
\end{aligned}
$$

In addition to the control variables used above, I include several additional controls in this model to address known determinants of merger premia, including an indicator variable for same industry, an indicator variable for government involvement, and indicator variable for unsolicited M\&A, an indicator variable for the use of a Big 4 auditor, and indicator variable for a transaction that takes the target private, and indicator for a competing bid on the target, and controls for size and ownership of the target prior to the M\&A. I present descriptive statistics for this sample in Table 12.

\section{INSERT TABLE 12 HERE}

I present my results in Table 13. Of all of the tax system characteristics that I examine, only tax regime and transfer pricing regulations return a significant coefficient. Specifically, I find that the acquirer pays a higher merger premium when the cross-border M\&A involves a territorial acquirer and a worldwide target. This is consistent with territorial acquirers being able to outbid worldwide acquirers in the global M\&A market, suggesting that worldwide tax system may put acquirers at a competitive disadvantage. I also find that merger premia are reduced when the acquirer is subject to transfer pricing regulations. This is consistent with cross-border 
M\&A facilitating tax avoidance through a profit-shifting channel. Because transfer pricing regulations limit firms' ability to generate tax savings through profit shifting mechanisms, acquirers subject to transfer pricing regulations may incur a higher cost to operate the subsidiary than an acquirer not subject to these rules.

\section{Conclusion}

This paper contributes to the literature on cross-border M\&As by examining the effects of tax system characteristics on the volume, direction, structure, and merger premia of crossborder M\&As. I find that naïve tax variables, such as the difference in top statutory corporate tax rates, do not fully explain the impact of taxes on cross-border M\&As. My evidence suggests that the volume of cross-border M\&A is affected by the difference in corporate income tax rates, the presence of CFC provisions, and the presence of transfer pricing rules. I further find that the direction of cross-border M\&A is affected by differences in corporate income tax rates and dividend withholding rates, tax regime, and the presence of CFC provisions and thin capitalization rules, and the allowance of a foreign tax credit. My results suggest that the presence of CFC provisions decreases both the volume of cross-border M\&A and the likelihood that a firm is the acquirer in cross-border M\&A. Regulations meant to limit tax avoidance through profit shifting also affects the global M\&A market. I find that thin capitalization rules reduce the likelihood of a country acting as the acquirer in cross border M\&A and that the presence of transfer pricing regulations reduces the incidence of cross-border M\&A.

In additional analyses, I examine determinants of the structure and merger premia of cross-border M\&As. Consistent with expectation, I find evidence that CFC provisions result in a smaller proportion of cross-border M\&A that results in control of the target. Interestingly, I find 
that when the target is located in a worldwide regime and the acquirer is located in a territorial regime, the cross-border M\&A is less likely to include an intermediary in a third country. These results suggest that firms respond to tax costs of cross-border M\&As by limiting the percent of the target acquired and employing the use of an intermediary in a third country.

However, I do find limited evidence that tax system characteristics influence the merger premia in cross-border M\&A. My results suggest that territorial acquirers may pay a higher merger premia, consistent with the territorial regime giving these acquirers a competitive advantage. I find that the presence of transfer pricing regulations in the acquirer country decrease the merger premia, consistent with transfer pricing regulations limiting tax avoidance by the post-merger firm through profit shifting.

This study contributes to the ongoing debate regarding U.S. tax reform and the recent passage of the TJCA2017, as a central focus of both has been the ability of U.S. multinationals to compete with firms in territorial regimes. My results suggest that criticisms of the U.S. worldwide tax system hurting U.S. firms in global markets are not baseless. However, the effect of CFC provisions, which were not affected by TCJA2017, may be more detrimental to U.S. firms in the cross-border M\&A market. 


\section{References}

Atwood, T., Huston, G., Wallace, D. (2016). The impact of home country taxation of foreign source income on firm performance: Beyond the worldwide versus territorial dichotomy. Working paper, University of Arkansas, Arizona State University, University of Central Florida.

Bekaert, G., Harvey, C. R., Lundblad, C. (2005). Does financial liberalization spur growth? Journal of Financial Economics, 77 (1): 3-55.

Belz, T., Robinson, L., Ruf, M., Steffens, C. (2013). Tax Avoidance as a Driver of Mergers and Acquisitions. Working Paper, Mannheim University, Dartmough College, Tuebingen University

Bradley, S., Ruf, M., \& Robinson, L. (2018). The Impact of Patent Box Regimes on the M\&A Market. Working Paper, Drexel University, Univesity of Tuebingen, Dartmouth College.

Col, B., Errunza, V. (2015) Havenly Acquisitions. Working Paper, Pace University, McGill University.

Crow, D., Fontanella-Khan, J., Murphy, M. (2015, March) Tax Inversion curb turns tables on US. Retrieved from https://www.ft.com/content/e1ba6eb0-ca5c-11e4-b8ff-00144feab7de

Di Giovanni, J. (2005). What drives capital flows? The case of cross-border M\&A activity and financial deepening. Journal of International Economics, 65 (1): 127-149.

Djankov, S., La Porta, R., Lopez-de-Silanes, F., \& Shleifer, A. (2008). The law and economics of self-dealing. Journal of Financial Economics, 88 (3): 430-465.

Dyreng, S. D., Lindsey, B. P., Markle, K. S., \& Shackelford, D. A. (2015). The effect of tax and nontax country characteristics on the global equity supply chains of US multinationals. Journal of Accounting and Economics, 59 (2): 182-202.

Erel, I., Liao, R. C., \& Weisbach, M. S. (2012). Determinants of cross-border mergers and acquisitions. The Journal of Finance, 67 (3): 1045-1082.

E\&Y (2015, March). Buying and selling: Cross-border mergers and acquisitions and the US corporate income tax. Retrieved from http://businessroundtable.org/sites/default/files/reports/EY\%20BRT\%20Crossborder\%20MA\%20report\%202015\%2003\%2010.pdf

Feld, L. P., Ruf, M., Scheuering, U., Schreiber, U., \& Voget, J. (2013). Effects of territorial and worldwide corporation tax systems on outbound M\&As. ZEW-Centre for European Economic Research Discussion Paper, (13-088).

Hoffman, L., McKinnon, J. (September 21, 2015). Curbs don't stop tax-driven mergers. The Wall Street Journal. 
Huizinga, H. P., \& Voget, J. (2009). International taxation and the direction and volume of Cross-Border M\&As. The Journal of Finance, 64 (3): 1217-1249.

Huizinga, H., Voget, J., \& Wagner, W. (2012). Who bears the burden of international taxation? Evidence from cross-border M\&As. Journal of International Economics, 88 (1): 186-197.

JP Morgan. (2018, January). 2018 global M\&A outlook. Retrieved from https://www.jpmorgan.com/jpmpdf/1320744801603.pdf

Klassen, K. J., \& Laplante, S. K. (2012). Are US multinational corporations becoming more aggressive income shifters? Journal of Accounting Research, 50 (5): 1245-1285.

Markle, K., \& Robinson, L. (2012). Tax haven use across international tax regimes. Working Paper, University of Iowa, Dartmouth College.

Markle, K. (2016). A comparison of the tax-motivated income shifting of multinationals in territorial and worldwide Countries. Contemporary Accounting Research, 33 (1): 7-43.

Mescall, D., \& Klassen, K. J. (2014). How does transfer pricing risk affect premia in crossborder mergers and acquisitions? Working Paper, University of Saskatchewan, University of Waterloo.

Mider, Zachary. (2017, March) Tracking tax runaways. Retrieved from https://www.bloomberg.com/graphics/tax-inversion-tracker/

Musgrave, P. (1969). United States taxation of foreign investment income: Issues and arguments. Harvard Law School.

Richman, P. (1963) Taxation of Foreign Investment Income: An economic analysis. Johns Hopkins Press.

Rossi, S., \& Volpin, P. F. (2004). Cross-country determinants of mergers and acquisitions. Journal of Financial Economics, 74 (2): 277-304. 


\section{Appendix 1: Variable Descriptions}

\begin{tabular}{|c|c|}
\hline Variable & Variable Definition \\
\hline CBMA_Volume & $\begin{array}{l}\text { The total number of cross-border deals in year } t \text { in which the target is } \\
\text { from country } i \text { and the acquirer is from country } j \text {, scaled by the sum of } \\
\text { the total number of domestic M\&As in country } j \text { and in country } i \text { in } \\
\text { year } t \text { then multiplied by } 100 \text {. (Source: Security Data Corporation's } \\
\text { (SDC) Mergers and Corporate Transactions database) }\end{array}$ \\
\hline CBMA_Direction & $\begin{array}{l}\text { The total number of cross-border deals in year } t \text { in which the target is } \\
\text { from country } i \text { and the acquirer is from country } j \text {, scaled by the sum of } \\
\text { the total number of cross-border M\&As between country } i \text { and } j \text { in year } \\
t \text { then multiplied by } 100 \text {. (Source: Security Data Corporation's (SDC) } \\
\text { Mergers and Corporate Transactions database) }\end{array}$ \\
\hline CL_TVolume & $\begin{array}{l}\text { The total number of cross-border deals in year } t \text { in which the target is } \\
\text { from country } i \text {, scaled by the total number of domestic M\&As in } \\
\text { country } i \text { in year } t \text { then multiplied by } 100 \text {. (Source: Security Data } \\
\text { Corporation's (SDC) Mergers and Corporate Transactions database) }\end{array}$ \\
\hline CL_AVolume & $\begin{array}{l}\text { The total number of cross-border deals in year } t \text { in which the acquirer is } \\
\text { from country } j \text {, scaled by the total number of domestic M\&As in } \\
\text { country } j \text { in year } t \text { then multiplied by } 100 \text {. (Source: Security Data } \\
\text { Corporation's (SDC) Mergers and Corporate Transactions database) }\end{array}$ \\
\hline$C L \_$Direction & $\begin{array}{l}\text { The total number of cross-border deals in year } t \text { in which the target is } \\
\text { from country } i \text {, scaled by the sum of the total number of cross-border } \\
\text { M\&As in which the target is from country } i \text { and the acquirer is from } \\
\text { country } i \text { in year } t \text { then multiplied by } 100 \text {. (Source: Security Data } \\
\text { Corporation's (SDC) Mergers and Corporate Transactions database) }\end{array}$ \\
\hline CBMA_Control & $\begin{array}{l}\text { The total number of cross-border deals in year } t \text { in which the target is } \\
\text { from country } i \text {, the acquirer is from country } j \text { and the acquirer owns } \\
\text { over } 50 \% \text { of the target following the M\&A transaction, scaled by the } \\
\text { total number of cross-border deals in year } t \text { in which the target is from } \\
\text { country } i \text { and the acquirer is from country } j \text { in year } t \text { then multiplied by } \\
100 \text {. (Source: Security Data Corporation's (SDC) Mergers and } \\
\text { Corporate Transactions database) }\end{array}$ \\
\hline CBMA_Intermediary & $\begin{array}{l}\text { The total number of cross-border deals in year } t \text { in which the target is } \\
\text { from country } i \text {, the acquirer is from country } j \text { and the immediate } \\
\text { acquirer is from neither country } i \text { nor } j \text {, scaled by the total number of } \\
\text { cross-border deals in year } t \text { in which the target is from country } i \text { and the } \\
\text { acquirer is from country } j \text { in year } t \text { then multiplied by } 100 \text {. (Source: } \\
\text { Security Data Corporation's (SDC) Mergers and Corporate } \\
\text { Transactions database) }\end{array}$ \\
\hline CBMA_Erel & $\begin{array}{l}\text { The total number of cross-border deals in year } t \text { in which the target is } \\
\text { from country } i \text { and the acquirer is from country } j \text {, scaled by the sum of } \\
\text { the total number of cross-border M\&As between country } i \text { and } j \text { and the }\end{array}$ \\
\hline
\end{tabular}


Trate_CorpIncTax

Diff_Trate_CorpIncTax

Trate_Dividends

Diff_Trate_Dividends

$W W$

Aww_Tterr

Aterr_Tww total number of domestic M\&As in country $i$ in year $t$ then multiplied by 100. (Source: Security Data Corporation's (SDC) Mergers and Corporate Transactions database)

The difference between the top statutory corporate income tax rate in the country. (Source: E\&Y Worldwide Corporate Tax Guides and the PwC Worldwide Tax Summaries)

The difference between the top statutory corporate income tax rate in the acquirer $(j$ ) and target $(i)$ countries. (Source: E\&Y Worldwide Corporate Tax Guides and the PwC Worldwide Tax Summaries)

the rate of withholding on dividends paid from the target country $(i)$ to the acquirer country $(j)$, where rates may be reduced under existing tax treaties (Source: E\&Y Worldwide Corporate Tax Guides and the PwC Worldwide Tax Summaries)

The difference between the rate of withholding on dividends paid from the target country $(i)$ to the acquirer country $(j)$ and the rate of withholding on dividends paid from the target country $(i)$ to the acquirer country $(j)$, where both rates are reduced under existing tax treaties where applicable (Source: E\&Y Worldwide Corporate Tax Guides and the PwC Worldwide Tax Summaries)

An indicator variable set equal to one if the country has a worldwide tax system, and zero otherwise, where the tax system is considered territorial if it exempts at least $95 \%$ of foreign dividends paid out of active income by a subsidiary that is at least $25 \%$ owned as determined with respect to the specific acquirer country (Source: E\&Y Worldwide Corporate Tax Guides and the PwC Worldwide Tax Summaries)

An indicator variable set equal to one if the acquirer $(j)$ country has a worldwide tax system and the target $(i)$ country has a territorial tax system, and zero otherwise, where the tax system is considered territorial if it exempts at least $95 \%$ of foreign dividends paid out of active income by a subsidiary that is at least $25 \%$ owned as determined with respect to the specific acquirer country (Source: E\&Y Worldwide Corporate Tax Guides and the PwC Worldwide Tax Summaries)

An indicator variable set equal to one if the acquirer $(j)$ country has a worldwide tax system and the target $(i)$ country has a territorial tax system, and zero otherwise, where the tax system is considered territorial if it exempts at least $95 \%$ of foreign dividends paid out of active income by a subsidiary that is at least $25 \%$ owned as determined with respect to the specific acquirer country (Source: E\&Y Worldwide Corporate Tax Guides and the PwC Worldwide Tax Summaries) 
CFC

Aonly_CFC

Tonly_CFC

ThinCapitalization

Aonly_Thincapitalization

Tonly_Thincapitalization

TransferPricing

Aonly_TransferPricing

Tonly_TransferPricing

FTC

Tonly_FTC
An indicator variable set equal to one if the country has Controlled Foreign Corporation provisions, and zero otherwise (Source: E\&Y Worldwide Corporate Tax Guides and the PwC Worldwide Tax Summaries)

An indicator variable set equal to one if the acquirer $(j)$ country has Controlled Foreign Corporation provisions and the target $(i)$ country does not, and zero otherwise (Source: E\&Y Worldwide Corporate Tax Guides and the PwC Worldwide Tax Summaries) An indicator variable set equal to one if the target (i) country has Controlled Foreign Corporation provisions and the acquirer $(j)$ country does not, and zero otherwise (Source: E\&Y Worldwide Corporate Tax Guides and the PwC Worldwide Tax Summaries) An indicator variable set equal to one if the country has thin capitalization rules, and zero otherwise (Source: E\&Y Worldwide Corporate Tax Guides and the PwC Worldwide Tax Summaries) An indicator variable set equal to one if the acquirer $(j)$ country has thin capitalization rules and the target $(i)$ country does not, and zero otherwise (Source: E\&Y Worldwide Corporate Tax Guides and the PwC Worldwide Tax Summaries)

An indicator variable set equal to one if the target (i) country has thin capitalization rules and the acquirer $(j)$ country does not, and zero otherwise (Source: E\&Y Worldwide Corporate Tax Guides and the PwC Worldwide Tax Summaries)

An indicator variable set equal to one if the country has specific transfer pricing regulations, and zero otherwise (Source: E\&Y Worldwide Corporate Tax Guides and the PwC Worldwide Tax Summaries)

An indicator variable set equal to one if the acquirer $(j)$ country has specific transfer pricing regulations and the target $(i)$ country does not, and zero otherwise (Source: E\&Y Worldwide Corporate Tax Guides and the PwC Worldwide Tax Summaries)

An indicator variable set equal to one if the target $(i)$ country has specific transfer pricing regulations and the acquirer $(j)$ country does not, and zero otherwise (Source: E\&Y Worldwide Corporate Tax Guides and the PwC Worldwide Tax Summaries)

An indicator variable set equal to one if the country allows a foreign tax credit for foreign taxes paid on non-exempt foreign profits, and zero otherwise (Source: E\&Y Worldwide Corporate Tax Guides and the PwC Worldwide Tax Summaries) An indicator variable set equal to one if the acquirer ( $j$ ) country allows a foreign tax credit for foreign taxes paid on non-exempt 
Aonly_FTC

IPBox

Aonly_IPBox

Tonly_IPBox

Xrate

Diff_Xrate

RealRI

Diff_RealRI

DisclosureIndex

foreign profits and the target (i) country does not, and zero otherwise (Source: E\&Y Worldwide Corporate Tax Guides and the PwC Worldwide Tax Summaries)

An indicator variable set equal to one if the target (i) country allows a foreign tax credit for foreign taxes paid on non-exempt foreign profits and the acquirer (j) country does not, and zero otherwise (Source: E\&Y Worldwide Corporate Tax Guides and the PwC Worldwide Tax Summaries)

An indicator variable set equal to one if the country exempts all or a portion of income derived from qualifying intellectual property or taxes this income at a reduced tax rate, and zero otherwise (Source: E\&Y Worldwide Corporate Tax Guides and the PwC Worldwide Tax Summaries)

An indicator variable set equal to one if the acquirer $(j)$ country exempts all or a portion of income derived from qualifying intellectual property or taxes this income at a reduced tax rate and the target (i) country does not, and zero otherwise (Source: E\&Y Worldwide Corporate Tax Guides and the PwC Worldwide Tax Summaries)

An indicator variable set equal to one if the target $(i)$ country exempts all or a portion of income derived from qualifying intellectual property or taxes this income at a reduced tax rate and the acquirer (j) country does not, and zero otherwise (Source: E\&Y Worldwide Corporate Tax Guides and the PwC Worldwide Tax Summaries)

The annual real stock market return of value-weighted index (Source:

Datastream)

The difference between the annual real stock market return of valueweighted indices in the acquirer $(j)$ and target $(i)$ countries. Valueweighted return indices in local currency (Source: Datastream) are deflated by the 2010 consumer price index in each country (Source: Worldbank)

The annual real bilateral U.S. dollar exchange rate return (Source: Datastream)

The difference between the annual real bilateral U.S. dollar exchange rate return of the acquirer $(j)$ and target $(i)$ countries. Nominal exchange rates (Source: Datastream) are deflated by the 2010 consumer price index in each country (Source: Worldbank)

The country's value in the Disclosure Index, in which a 10 indicates the highest level of disclosure and a zero indicates the lowest level of disclosure (Source: WorldBank) 
Diff_DisclosureIndex

Anti_SelfDeal

Diff_Anti_SelfDeal

SameLanguage

SameReligion

GCDist

MaxTrade

GDP

Diff_GDP

GDPgrowth

Diff_GDPgrowth

Premia

SameIndustry

Gov_Involvement
The difference between the acquirer $(j)$ and target $(i)$ countries in the Disclosure Index, in which a 10 indicates the highest level of disclosure and a zero indicates the lowest level of disclosure (Source: WorldBank) The Anti-Self Dealing Index, in which a 1 indicates good governance and zero indicates a low level of governance (Source: Djankov, La Porta, Lopez-de-Silanes, and Shleifer 2008)

The difference between the acquirer $(j)$ and target $(i)$ countries in the Anti-Self Dealing Index, in which a 1 indicates good governance and zero indicates a low level of governance (Source: Djankov, La Porta, Lopez-de-Silanes, and Shleifer 2008)

An indicator variable equal to one if the acquirer $(j)$ and target $(i)$ countries share a primary language, and zero otherwise (Source: FBI World Factbook)

An indicator variable equal to one if the acquirer $(j)$ and target $(i)$ countries share a primary religion, and zero otherwise (Source: FBI World Factbook)

The great circle distance between the capital cities of the acquirer $(j)$ and target (i) countries, calculated using he longitude and latitude of capital cities (Source: www.WorldData.info)

The maximum of bilateral imports and exports between acquirer $(j)$ and target (i) countries, where imports (exports) are measured as the total proportion of the target country's imports (exports) from (to) the acquirer country (Source: UN Commodity Trade Database)

The natural log of the per capita GDP (Source: WorldBank)

The difference in the natural log of the per capita GDP (Source: WorldBank)

Tthe annual growth of the per capita GDP (Source: WorldBank)

The difference in the annual growth of the per capita GDP (Source: WorldBank)

The four-week merger premia, calculated as the difference between the initial bid price and the share price four weeks prior to the day of the initial bid, scaled by the price four weeks prior to the day of the initial bid (Source: Security Data Corporation's (SDC) Mergers and Corporate Transactions database)

An indicator variable equal to one if the acquirer firm and the target firm have the same two-digit SIC number, and zero otherwise (Source: Security Data Corporation's (SDC) Mergers and Corporate Transactions database)

An indicator variable equal to one if there is government involvement in the M\&A, and zero otherwise (Source: Security Data Corporation's (SDC) Mergers and Corporate Transactions database) 
Unsolicited

$\operatorname{BigN}$

Private

Size

CompetingBid

ToeHold
An indicator variable equal to one if bid was unsolicited, and zero otherwise (Source: Security Data Corporation's (SDC) Mergers and Corporate Transactions database)

An indicator variable equal to one if the auditor is $\mathrm{KPMG}, \mathrm{PwC}$, E\&Y or Deloitte, and zero otherwise (Source: Security Data Corporation's (SDC) Mergers and Corporate Transactions database) An indicator variable equal to one if the acquirer firm is taking the target private through the M\&A, and zero otherwise. (Source:

Security Data Corporation's (SDC) Mergers and Corporate Transactions database)

The natural $\log$ of the deal value in millions (Source: Security Data Corporation's (SDC) Mergers and Corporate Transactions database) An indicator variable equal to one if the number of bidders for the target firm exceeds one, and zero otherwise (Source: Security Data Corporation's (SDC) Mergers and Corporate Transactions database) The percentage of the target owned by the acquirer prior to the deal announcement (Source: Security Data Corporation's (SDC) Mergers and Corporate Transactions database) 


\section{Appendix 2: Erel et. al (2012) Replication}

In my primary analysis, I deviate from the dependent variable used in Erel et al. (2012) in order to separately examine the effect of tax system characteristics on both the volume and the direction of cross-border M\&A. In this appendix, I use the dependent variable from Erel et al. (2012) to jointly consider these effects. Descriptive statistics for all variables in this test can be found in Table 2. Of note is that the dependent variable used in Erel et al. (2012) and in these regressions is highly right-skewed. Though this skewness is due to the pattern of M\&A itself, and is similar to the skewness of MaxTrade, another measure of cross-border activity, I urge the reader to interpret the results of OLS regression with this dependent variable with extreme caution. While skewness in the dependent variable does not violate OLS assumptions, it does make OLS regression, which models the mean of the distribution, less appropriate.

\section{INSERT APPENDIX 2 TABLE HERE}

Similar to Erel et al. (2012), I also find that acquirers more frequently acquire in countries with lower statutory tax rates. I also find evidence that firms acquire targets in countries with a lower dividend withholding tax rates, reducing the cost of repatriating the profits of the foreign subsidiary.

Contrary to expectations, I find that cross-border M\&As occur more (less) frequently between an acquirer (target) subject to CFC provisions and a target (acquirer) that is not than between two firms with similar treatment of income from controlled foreign subsidiaries. Although CFC provisions increase the tax cost of operating a foreign subsidiary, this result suggests that the applicability of CFC provisions does not deter, but rather encourages, crossborder M\&A. This is not consistent with my findings in Tables 3 and 5 above. 
I find that cross-border M\&As occur less (more) frequently between an acquirer (target) subject to transfer pricing regulations and a target (acquirer) that is not than between two firms with similar anti-avoidance regimes. This is consistent with transfer pricing regulations reducing the profitability of cross-border M\&A by limiting the post-merger firms' ability to avoid taxes through income shifting, provided that post-merger firms, on average, prefer to shift income away from the acquirer.

Finally, I also find that cross-border M\&A is more likely when only the target firm is in an IP Box regime. This would be consistent with firms acquiring targets in a favorable regime to facilitate moving IP to a tax-preferred jurisdiction.

Across known non-tax determinants of the volume of cross-border M\&As, my results are largely consistent with prior literature. Consistent with Erel et al. (2012), I find that geographic distance, existing trade, and cultural similarity are important determinants of cross-border M\&As. I also find evidence that acquirers are likely to acquire in countries with poorer governance and lower GDP per capita. In my sample, however, I do not find that firms exploit valuation effects caused by currency exchange rate or stock market returns in cross-border M\&A. 


\section{Table 1: Number of Mergers by Country Pair}

Table 1 presents the number of M\&A transactions occurring between 2006 and 2015, inclusive. The columns represent the countries of the acquirers, while the rows represent the countries of the targets. Therefore, the diagonal entries of the matrix represent the domestic mergers that occurred within the country, while the off-diagonal entries are the number of deals between an ordered country pair.

\begin{tabular}{|c|c|c|c|c|c|c|c|c|c|c|c|c|c|c|c|c|c|c|c|c|c|c|c|c|c|}
\hline & (1) & (2) & (3) & (4) & (5) & (6) & (7) & (8) & (9) & (10) & (11) & (12) & (13) & (14) & (15) & (16) & (17) & (18) & (19) & (20) & (21) & (22) & (23) & (24) & (25) \\
\hline (1) Australia & 7686 & 13 & 9 & 13 & 0 & 230 & 0 & 0 & 1 & 11 & 0 & 0 & 16 & 68 & 80 & 1 & 0 & 69 & 22 & 32 & 3 & 19 & 0 & 185 & 0 \\
\hline (2) Austria & 7 & 613 & 6 & 2 & 0 & 7 & 0 & 0 & 3 & 5 & 0 & 0 & 7 & 25 & 220 & 0 & 1 & 5 & 0 & 3 & 5 & 29 & 0 & 14 & 0 \\
\hline (3) Belgium & 28 & 13 & 749 & 4 & 0 & 28 & 1 & 0 & 0 & 8 & 0 & 5 & 9 & 230 & 90 & 2 & 0 & 13 & 0 & 25 & 3 & 12 & 0 & 23 & 0 \\
\hline (4) Brazil & 39 & 9 & 16 & 2217 & 0 & 108 & 29 & 13 & 0 & 11 & 0 & 0 & 8 & 153 & 74 & 0 & 1 & 18 & 0 & 14 & 19 & 68 & 1 & 84 & 0 \\
\hline (5) Bulgaria & 0 & 18 & 3 & 0 & 176 & 1 & 0 & 0 & 4 & 0 & 0 & 0 & 3 & 12 & 15 & 17 & 1 & 1 & 0 & 4 & 1 & 6 & 0 & 1 & 0 \\
\hline (6) Canada & 139 & 11 & 43 & 17 & 0 & 9235 & 5 & 6 & 0 & 22 & 0 & 1 & 14 & 146 & 56 & 2 & 2 & 49 & 6 & 25 & 40 & 18 & 0 & 86 & 1 \\
\hline (7) Chile & 19 & 2 & 2 & 8 & 0 & 39 & 498 & 7 & 0 & 2 & 0 & 0 & 1 & 8 & 12 & 0 & 0 & 4 & 0 & 1 & 0 & 5 & 0 & 14 & 0 \\
\hline (8) Colombia & 4 & 0 & 2 & 21 & 0 & 71 & 16 & 208 & 0 & 3 & 0 & 0 & 0 & 22 & 4 & 0 & 0 & 4 & 0 & 3 & 0 & 3 & 0 & 7 & 0 \\
\hline (9) Czech Republic & 4 & 31 & 9 & 1 & 0 & 7 & 0 & 0 & 420 & 8 & 0 & 0 & 11 & 52 & 80 & 2 & 5 & 12 & 0 & 5 & 10 & 14 & 0 & 14 & 0 \\
\hline (10) Denmark & 8 & 6 & 11 & 1 & 1 & 12 & 2 & 0 & 0 & 1132 & 0 & 1 & 42 & 47 & 74 & 1 & 0 & 4 & 1 & 9 & 4 & 13 & 0 & 20 & 0 \\
\hline (11) Ecuador & 4 & 0 & 0 & 0 & 0 & 9 & 0 & 8 & 0 & 0 & 14 & 0 & 0 & 1 & 1 & 0 & 0 & 0 & 0 & 0 & 0 & 0 & 0 & 0 & 0 \\
\hline (12) Egypt & 3 & 0 & 0 & 0 & 0 & 9 & 0 & 0 & 0 & 1 & 0 & 234 & 0 & 9 & 5 & 3 & 0 & 7 & 0 & 0 & 0 & 3 & 0 & 5 & 0 \\
\hline (13) Finland & 9 & 4 & 7 & 0 & 0 & 28 & 0 & 2 & 0 & 47 & 0 & 0 & 1053 & 17 & 50 & 0 & 0 & 11 & 0 & 4 & 2 & 8 & 0 & 15 & 0 \\
\hline (14) France & 32 & 20 & 207 & 5 & 0 & 97 & 3 & 0 & 3 & 33 & 0 & 3 & 17 & 10009 & 296 & 2 & 2 & 40 & 1 & 25 & 24 & 147 & 0 & 99 & 0 \\
\hline (15) Germany & 56 & 269 & 62 & 5 & 2 & 88 & 0 & 0 & 17 & 75 & 0 & 3 & 56 & 356 & 6492 & 9 & 3 & 72 & 1 & 36 & 36 & 142 & 0 & 154 & 0 \\
\hline (16) Greece & 2 & 2 & 8 & 0 & 0 & 5 & 1 & 0 & 0 & 3 & 0 & 0 & 4 & 14 & 15 & 361 & 0 & 2 & 0 & 2 & 2 & 5 & 0 & 3 & 0 \\
\hline (17) Hungary & 2 & 22 & 5 & 0 & 0 & 2 & 0 & 0 & 8 & 3 & 0 & 0 & 4 & 27 & 54 & 0 & 128 & 1 & 0 & 2 & 3 & 4 & 0 & 9 & 0 \\
\hline (18) India & 35 & 11 & 13 & 3 & 0 & 35 & 0 & 0 & 0 & 12 & 0 & 2 & 9 & 113 & 119 & 1 & 1 & 4087 & 1 & 8 & 3 & 32 & 0 & 184 & 0 \\
\hline (19) Indonesia & 59 & 0 & 1 & 0 & 0 & 10 & 0 & 0 & 1 & 0 & 0 & 0 & 0 & 10 & 9 & 0 & 0 & 16 & 731 & 1 & 0 & 2 & 0 & 77 & 0 \\
\hline (20) Ireland-Rep & 11 & 4 & 3 & 1 & 0 & 23 & 0 & 0 & 0 & 3 & 0 & 1 & 1 & 33 & 23 & 0 & 0 & 3 & 0 & 467 & 1 & 7 & 0 & 8 & 0 \\
\hline (21) Israel & 4 & 0 & 4 & 1 & 0 & 27 & 0 & 0 & 0 & 0 & 0 & 0 & 0 & 16 & 10 & 0 & 0 & 9 & 0 & 6 & 339 & 5 & 0 & 5 & 0 \\
\hline (22) Italy & 14 & 51 & 29 & 5 & 1 & 27 & 0 & 0 & 3 & 15 & 0 & 3 & 16 & 237 & 170 & 5 & 3 & 39 & 1 & 8 & 9 & 2651 & 0 & 57 & 0 \\
\hline (23) Jamaica & 0 & 0 & 0 & 0 & 0 & 3 & 0 & 0 & 0 & 0 & 0 & 0 & 0 & 0 & 0 & 0 & 0 & 0 & 0 & 0 & 0 & 0 & 7 & 0 & 0 \\
\hline (24) Japan & 19 & 0 & 4 & 3 & 0 & 14 & 0 & 0 & 0 & 2 & 0 & 0 & 5 & 43 & 63 & 2 & 0 & 11 & 1 & 5 & 5 & 14 & 8 & 15895 & 0 \\
\hline (25) Kenya & 1 & 0 & 0 & 0 & 0 & 0 & 0 & 0 & 0 & 0 & 0 & 0 & 0 & 1 & 0 & 0 & 0 & 0 & 0 & 0 & 0 & 0 & 0 & 0 & 26 \\
\hline (26) Luxembourg & 5 & 1 & 27 & 0 & 0 & 6 & 0 & 0 & 1 & 1 & 0 & 0 & 0 & 35 & 24 & 0 & 0 & 2 & 0 & 4 & 0 & 13 & 0 & 8 & 0 \\
\hline (27) Malaysia & 42 & 0 & 1 & 0 & 0 & 11 & 0 & 1 & 0 & 1 & 0 & 0 & 1 & 13 & 16 & 0 & 0 & 14 & 14 & 2 & 0 & 3 & 0 & 98 & 0 \\
\hline (28) Mexico & 22 & 1 & 4 & 15 & 0 & 241 & 3 & 8 & 0 & 4 & 0 & 0 & 2 & 18 & 22 & 0 & 0 & 9 & 0 & 4 & 3 & 8 & 0 & 18 & 0 \\
\hline (29) Netherlands & 17 & 28 & 121 & 7 & 0 & 29 & 0 & 1 & 3 & 20 & 0 & 0 & 28 & 154 & 196 & 2 & 3 & 27 & 0 & 37 & 17 & 31 & 1 & 55 & 0 \\
\hline (30) New Zealand & 316 & 0 & 2 & 0 & 0 & 37 & 0 & 0 & 0 & 4 & 0 & 0 & 1 & 10 & 17 & 0 & 0 & 6 & 1 & 0 & 5 & 3 & 0 & 31 & 0 \\
\hline (31) Norway & 3 & 10 & 4 & 3 & 0 & 27 & 0 & 0 & 1 & 102 & 0 & 0 & 52 & 38 & 58 & 5 & 1 & 9 & 1 & 4 & 2 & 5 & 0 & 13 & 0 \\
\hline (32) Pakistan & 0 & 1 & 0 & 0 & 0 & 1 & 0 & 0 & 0 & 1 & 0 & 0 & 0 & 0 & 2 & 0 & 0 & 0 & 0 & 0 & 0 & 0 & 0 & 2 & 1 \\
\hline (33) Peru & 22 & 1 & 4 & 15 & 0 & 114 & 30 & 13 & 0 & 2 & 1 & 0 & 0 & 3 & 3 & 0 & 0 & 2 & 0 & 0 & 2 & 0 & 0 & 7 & 0 \\
\hline (34) Philippines & 27 & 1 & 1 & 0 & 0 & 9 & 0 & 0 & 0 & 2 & 0 & 0 & 0 & 1 & 3 & 0 & 0 & 3 & 1 & 1 & 0 & 0 & 0 & 39 & 0 \\
\hline (35) Poland & 13 & 29 & 15 & 0 & 0 & 10 & 0 & 0 & 9 & 17 & 0 & 1 & 19 & 67 & 117 & 5 & 4 & 8 & 0 & 4 & 8 & 24 & 0 & 13 & 0 \\
\hline (36) Portugal & 3 & 1 & 5 & 16 & 0 & 10 & 0 & 0 & 0 & 0 & 0 & 0 & 0 & 36 & 14 & 0 & 2 & 3 & 0 & 2 & 0 & 5 & 0 & 8 & 0 \\
\hline (37) Romania & 1 & 28 & 6 & 0 & 2 & 3 & 0 & 0 & 5 & 1 & 0 & 0 & 3 & 29 & 19 & 19 & 12 & 4 & 0 & 3 & 5 & 14 & 0 & 5 & 0 \\
\hline (38) Russian Fed & 7 & 25 & 14 & 0 & 2 & 33 & 0 & 0 & 8 & 13 & 0 & 0 & 69 & 70 & 120 & 3 & 2 & 6 & 0 & 7 & 8 & 34 & 0 & 34 & 0 \\
\hline (39) Singapore & 88 & 3 & 2 & 0 & 0 & 14 & 0 & 0 & 0 & 3 & 0 & 0 & 4 & 28 & 30 & 0 & 0 & 56 & 33 & 8 & 1 & 13 & 0 & 125 & 0 \\
\hline (40) Slovak Rep & 0 & 2 & 0 & 0 & 0 & 1 & 0 & 0 & 14 & 2 & 0 & 0 & 3 & 7 & 8 & 0 & 0 & 1 & 0 & 0 & 2 & 0 & 0 & 2 & 0 \\
\hline (41) S Korea & 16 & 1 & 5 & 0 & 0 & 10 & 0 & 0 & 0 & 5 & 0 & 0 & 3 & 25 & 31 & 0 & 0 & 5 & 0 & 2 & 3 & 2 & 0 & 127 & 0 \\
\hline (42) Spain & 24 & 6 & 44 & 10 & 0 & 52 & 8 & 2 & 4 & 21 & 0 & 3 & 26 & 317 & 154 & 7 & 0 & 22 & 1 & 19 & 12 & 98 & 0 & 50 & 0 \\
\hline (43) Sri Lanka & 2 & 0 & 0 & 0 & 0 & 3 & 0 & 0 & 0 & 0 & 0 & 0 & 0 & 1 & 0 & 0 & 0 & 10 & 1 & 0 & 0 & 0 & 0 & 7 & 0 \\
\hline (44) Sweden & 22 & 9 & 9 & 1 & 0 & 42 & 0 & 0 & 1 & 202 & 0 & 0 & 232 & 69 & 105 & 0 & 0 & 17 & 0 & 12 & 4 & 18 & 0 & 30 & 0 \\
\hline (45) Switzerland & 14 & 42 & 12 & 2 & 0 & 25 & 0 & 0 & 0 & 15 & 0 & 2 & 10 & 124 & 318 & 0 & 1 & 18 & 0 & 10 & 13 & 38 & 0 & 41 & 0 \\
\hline (46) Thailand & 14 & 0 & 3 & 1 & 1 & 0 & 0 & 0 & 0 & 0 & 0 & 0 & 1 & 7 & 4 & 0 & 0 & 12 & 3 & 0 & 2 & 2 & 0 & 117 & 0 \\
\hline (47) Turkey & 7 & 24 & 10 & 4 & 1 & 20 & 0 & 0 & 6 & 2 & 0 & 3 & 4 & 63 & 56 & 8 & 1 & 14 & 0 & 5 & 2 & 26 & 0 & 36 & 0 \\
\hline (48) U.K. & 268 & 24 & 71 & 8 & 1 & 341 & 1 & 1 & 3 & 59 & 0 & 3 & 31 & 442 & 344 & 5 & 0 & 174 & 2 & 283 & 35 & 108 & 1 & 189 & 0 \\
\hline (49) U.S. & 586 & 62 & 83 & 75 & 4 & 2684 & 9 & 14 & 6 & 84 & 2 & 7 & 93 & 652 & 616 & 19 & 5 & 383 & 3 & 327 & 221 & 176 & 2 & 982 & 0 \\
\hline (50) Venezuela & 0 & 0 & 0 & 0 & 0 & 1 & 1 & 1 & 0 & 1 & 1 & 0 & 0 & 0 & 0 & 0 & 0 & 1 & 0 & 0 & 0 & 0 & 0 & 0 & 0 \\
\hline
\end{tabular}




\section{Table 1 (continued): Number of Mergers by Country Pair}

\begin{tabular}{|c|c|c|c|c|c|c|c|c|c|c|c|c|c|c|c|c|c|c|c|c|c|c|c|c|c|}
\hline & (26) & (27) & (28) & (29) & (30) & (31) & (32) & (33) & (34) & (35) & (36) & (37) & (38) & (39) & (40) & (41) & (42) & (43) & (44) & (45) & (46) & (47) & (48) & (49) & (50) \\
\hline (1) Australia & 16 & 95 & 2 & 73 & 161 & 20 & 0 & 0 & 13 & 1 & 2 & 0 & 2 & 234 & 0 & 28 & 19 & 0 & 28 & 84 & 27 & 0 & 477 & 977 & 0 \\
\hline (2) Austria & 15 & 0 & 3 & 23 & 0 & 3 & 0 & 0 & 0 & 7 & 2 & 1 & 11 & 0 & 1 & 1 & 1 & 0 & 14 & 74 & 0 & 1 & 42 & 79 & 0 \\
\hline (3) Belgium & 33 & 2 & 1 & 175 & 0 & 5 & 0 & 0 & 0 & 1 & 0 & 0 & 6 & 6 & 0 & 3 & 16 & 0 & 32 & 35 & 0 & 1 & 96 & 176 & 0 \\
\hline (4) Brazil & 21 & 3 & 40 & 40 & 4 & 15 & 0 & 3 & 0 & 0 & 46 & 0 & 9 & 16 & 0 & 7 & 89 & 0 & 25 & 80 & 2 & 0 & 130 & 654 & 2 \\
\hline (5) Bulgaria & 10 & 0 & 1 & 7 & 0 & 2 & 0 & 0 & 1 & 4 & 0 & 3 & 9 & 0 & 0 & 0 & 0 & 0 & 9 & 9 & 0 & 0 & 23 & 34 & 0 \\
\hline (6) Canada & 19 & 14 & 18 & 74 & 6 & 22 & 1 & 7 & 5 & 6 & 2 & 0 & 21 & 22 & 0 & 32 & 14 & 1 & 43 & 80 & 4 & 1 & 316 & 2423 & 1 \\
\hline (7) Chile & 1 & 0 & 4 & 2 & 0 & 1 & 0 & 22 & 0 & 0 & 1 & 0 & 0 & 0 & 0 & 4 & 25 & 0 & 7 & 4 & 0 & 0 & 17 & 66 & 1 \\
\hline (8) Colombia & 2 & 1 & 24 & 3 & 0 & 1 & 0 & 16 & 1 & 0 & 1 & 0 & 0 & 0 & 0 & 1 & 32 & 0 & 5 & 10 & 0 & 0 & 28 & 93 & 3 \\
\hline (9) Czech Republic & 29 & 0 & $\frac{24}{2}$ & 59 & 0 & 1 & 0 & 0 & 1 & 25 & 2 & 1 & 15 & 1 & 12 & 5 & 12 & 0 & 19 & 23 & 0 & 0 & 72 & 79 & 0 \\
\hline (10) Denmark & 7 & 1 & 1 & 54 & 1 & 130 & 0 & 0 & 1 & 6 & 1 & 0 & 5 & 7 & 1 & 2 & 3 & 0 & 231 & 27 & 2 & 0 & 117 & 167 & 0 \\
\hline (11) Ecuador & 0 & 0 & 4 & 1 & 0 & 0 & 0 & 5 & 0 & 0 & 0 & 0 & 0 & 0 & 0 & 0 & 5 & 0 & 0 & 0 & 0 & 0 & 0 & 11 & 1 \\
\hline (12) Egypt & 0 & 1 & 0 & 4 & 0 & 0 & 0 & 0 & 0 & 0 & 0 & 0 & 1 & 1 & 0 & 0 & 1 & 0 & 2 & 1 & 0 & 0 & 22 & 29 & 0 \\
\hline (13) Finland & 5 & 0 & 0 & 35 & 0 & 37 & 0 & 0 & 0 & 1 & 1 & 0 & 13 & 3 & 0 & 1 & 9 & 0 & 246 & 9 & 0 & 0 & 135 & 107 & 0 \\
\hline (14) France & 103 & 1 & 1 & 145 & 4 & 25 & 1 & 0 & 0 & 5 & 12 & 0 & 17 & 15 & 0 & 12 & 132 & 0 & 94 & 192 & 6 & 4 & 457 & 822 & 0 \\
\hline (15) Germany & 90 & 17 & 8 & 279 & 9 & 48 & 0 & 0 & 1 & 38 & 13 & 1 & 44 & 25 & 1 & 31 & 72 & 0 & 160 & 470 & 7 & 13 & 577 & 1187 & 0 \\
\hline (16) Greece & 4 & 0 & 0 & 5 & 0 & 1 & 0 & 0 & 0 & 1 & 0 & 0 & 6 & 0 & 0 & 1 & 1 & 0 & 3 & 5 & 0 & 2 & 28 & 18 & 0 \\
\hline (17) Hungary & 0 & 0 & 0 & 18 & 0 & 2 & 0 & 0 & 0 & 10 & 0 & 3 & 2 & 1 & 2 & 0 & 0 & 0 & 5 & 13 & 3 & 2 & 33 & 35 & 0 \\
\hline (18) India & 15 & 55 & 2 & 33 & 0 & 18 & 0 & 0 & 2 & 3 & 3 & 0 & 7 & 129 & 2 & 14 & 17 & 6 & 26 & 58 & 5 & 1 & 215 & 837 & 0 \\
\hline (19) Indonesia & 3 & 103 & 1 & 12 & 0 & 2 & 0 & 0 & 7 & 0 & 0 & 1 & 1 & 207 & 0 & 37 & 3 & 0 & 1 & 8 & 24 & 3 & 51 & 44 & 0 \\
\hline (20) Ireland-Rep & 10 & 0 & 3 & 23 & 3 & 3 & 0 & 0 & 1 & 1 & 2 & 0 & 5 & 7 & 1 & 0 & 5 & 0 & 11 & 14 & 2 & 1 & 228 & 248 & 0 \\
\hline (21) Israel & 6 & 1 & 0 & 6 & 0 & 0 & 0 & 0 & 0 & 0 & 0 & 0 & 7 & 3 & 0 & 2 & 2 & 0 & 4 & 9 & 0 & 1 & 27 & 239 & 0 \\
\hline (22) Italy & 80 & 3 & 1 & 77 & 1 & 3 & 1 & 1 & 0 & 4 & 3 & 4 & 26 & 9 & 0 & 12 & 68 & 0 & 32 & 106 & 5 & 7 & 228 & 400 & 0 \\
\hline (23) Jamaica & 0 & 0 & 3 & 1 & 0 & 0 & 0 & 0 & 0 & 0 & 0 & 0 & 1 & 0 & 0 & 0 & 1 & 0 & 0 & 0 & 0 & 0 & 1 & 1 & 0 \\
\hline (24) Japan & 3 & 10 & 0 & 24 & 2 & 3 & 0 & 0 & 0 & 0 & 0 & 0 & 1 & 102 & 1 & 83 & 3 & 0 & 17 & 29 & 12 & 1 & 65 & 526 & 0 \\
\hline (25) Kenya & 0 & 0 & 0 & $\frac{24}{1}$ & 0 & 0 & 0 & 0 & 0 & 0 & 0 & 0 & 0 & 0 & 0 & 0 & 0 & 0 & 0 & 0 & 0 & 0 & 3 & 3 & 0 \\
\hline (26) Luxembourg & 41 & 1 & 3 & 10 & 0 & 1 & 0 & 0 & 0 & 4 & 1 & 0 & 2 & 5 & 0 & 5 & 3 & 0 & 9 & 15 & 0 & 0 & 36 & 48 & 0 \\
\hline (27) Malaysia & 4 & 3903 & 1 & 10 & 1 & 0 & 0 & 0 & 5 & 0 & 0 & 0 & 3 & 320 & 0 & 15 & 2 & 2 & 3 & 11 & 10 & 1 & 35 & 64 & 0 \\
\hline (28) Mexico & 3 & 1 & 462 & 15 & 1 & 2 & 0 & 1 & 3 & 0 & 2 & 0 & 0 & 3 & 0 & 4 & 54 & 0 & 7 & 9 & 0 & 0 & 35 & 276 & 1 \\
\hline (29) Netherlands & 32 & 7 & 2 & 2221 & 5 & 34 & 0 & 0 & 0 & 4 & 2 & 2 & 22 & 18 & 0 & 8 & 33 & 0 & 74 & 60 & 1 & 6 & 252 & 520 & 1 \\
\hline (30) New Zealand & 4 & 12 & 0 & 15 & 902 & $\frac{34}{1}$ & 0 & 0 & 2 & 0 & 1 & 0 & 2 & 40 & 0 & 3 & $\frac{3}{3}$ & 0 & 3 & 10 & 3 & 0 & 48 & 146 & 0 \\
\hline (31) Norway & 12 & 2 & 2 & 40 & 0 & 1785 & 0 & 0 & 0 & 8 & 1 & 0 & 3 & 23 & 0 & 8 & 6 & 0 & 327 & 18 & 5 & 1 & 145 & 185 & 0 \\
\hline (32) Pakistan & 0 & 3 & 0 & 4 & 0 & 0 & 45 & 0 & 1 & 0 & 0 & 0 & 0 & 3 & 0 & 1 & 0 & 0 & 0 & 0 & 0 & 1 & 7 & 8 & 0 \\
\hline (33) Peru & 0 & 0 & 12 & 5 & 0 & 1 & 0 & 253 & 0 & 0 & 1 & 0 & 2 & 0 & 0 & 3 & 29 & 0 & 1 & 4 & 0 & 0 & 11 & 45 & 0 \\
\hline (34) Philippines & 0 & 15 & 2 & 7 & 0 & 0 & 0 & 0 & 427 & 1 & 0 & 0 & 1 & 36 & 0 & 8 & 0 & 0 & 0 & 2 & 8 & 0 & 10 & 36 & 0 \\
\hline (35) Poland & 37 & 2 & 1 & 50 & 0 & 5 & 0 & 0 & 0 & 1419 & 4 & 2 & 5 & 2 & 3 & 3 & 14 & 0 & 37 & 23 & 1 & 0 & 124 & 160 & 0 \\
\hline (36) Portugal & 12 & 0 & 0 & 12 & 0 & 0 & 0 & 0 & 0 & 0 & 449 & 0 & 1 & 0 & 0 & 0 & 78 & 0 & 4 & 11 & 2 & 2 & 42 & 38 & 0 \\
\hline (37) Romania & 2 & 0 & 0 & 23 & 0 & 1 & 0 & 0 & 0 & 18 & 2 & 134 & 6 & 0 & 3 & 2 & 8 & 0 & 6 & 16 & 0 & 4 & 32 & 47 & 0 \\
\hline (38) Russian Fed & 35 & 0 & 1 & 149 & 2 & 17 & 0 & 0 & 0 & 24 & 0 & 0 & 10381 & 7 & 1 & 13 & 11 & 0 & 45 & 71 & 1 & 13 & 135 & 179 & 1 \\
\hline (39) Singapore & 3 & 225 & 0 & 12 & 2 & 13 & 0 & 0 & 5 & 0 & 0 & 0 & 0 & 1536 & 0 & 11 & 4 & 1 & 9 & 15 & 24 & 0 & 88 & 166 & 0 \\
\hline (40) Slovak Rep & 2 & 0 & 0 & 1 & 0 & 0 & 0 & 0 & 0 & 6 & 0 & 0 & 1 & 0 & 29 & 3 & 0 & 0 & 3 & 2 & 0 & 0 & 6 & 7 & 0 \\
\hline (41) S Korea & 3 & 9 & 2 & 12 & 0 & 2 & 0 & 0 & 0 & 0 & 0 & 0 & 5 & 40 & 0 & 6339 & 1 & 0 & 15 & 17 & 1 & 0 & 42 & 202 & 0 \\
\hline (42) Spain & 42 & 4 & 43 & 89 & 1 & 26 & 0 & 1 & 2 & 11 & 77 & 0 & 9 & 8 & 0 & 6 & 4432 & 0 & 55 & 80 & 1 & 2 & 318 & 421 & 0 \\
\hline (43) Sri Lanka & $\frac{42}{0}$ & 16 & 0 & 0 & 0 & 0 & 0 & 0 & 0 & 0 & 0 & 0 & 0 & 3 & 0 & 0 & $\frac{1452}{0}$ & 159 & 0 & 0 & 1 & 0 & 13 & $\frac{421}{3}$ & 0 \\
\hline (44) Sweden & 18 & 2 & 0 & 123 & 1 & 351 & 0 & 0 & 0 & 5 & 1 & 0 & 7 & 3 & 0 & 3 & 7 & 0 & 3578 & 52 & 0 & 2 & 241 & 307 & 0 \\
\hline (45) Switzerland & 22 & 5 & 0 & 40 & 1 & 10 & 0 & 0 & 2 & 7 & 1 & 0 & 24 & 14 & 0 & 5 & 9 & 0 & 46 & 1980 & 0 & 2 & 114 & 269 & 0 \\
\hline (46) Thailand & 0 & 63 & 0 & $\frac{40}{5}$ & 1 & 1 & 0 & 0 & 0 & 0 & 0 & 0 & 14 & 91 & 0 & 9 & 0 & 1 & $\frac{40}{2}$ & 6 & 1039 & 0 & 21 & 43 & 0 \\
\hline (47) Turkey & 9 & 10 & 1 & 38 & 0 & 2 & 1 & 0 & 0 & 9 & 4 & 0 & 15 & 12 & 0 & 5 & 19 & 0 & 22 & 26 & 3 & 759 & 68 & 100 & 0 \\
\hline (48) U.K. & 56 & 49 & 4 & 244 & 22 & 69 & 2 & 2 & 13 & 8 & 10 & 0 & 47 & 87 & 1 & 19 & 75 & 0 & 183 & 180 & 31 & 1 & 12458 & 2781 & 1 \\
\hline (49) U.S. & 78 & 29 & 105 & 327 & 48 & 94 & 2 & 6 & 36 & 8 & 6 & 0 & 71 & 122 & 0 & 160 & 150 & 3 & 284 & 422 & 19 & 10 & 1972 & 57205 & 2 \\
\hline (50) Venezuela & & & & & 0 & & & 0 & & 0 & 0 & 0 & & & 0 & & & 0 & & 0 & 0 & 0 & 0 & 2 & 53 \\
\hline
\end{tabular}




\section{Table 2: Descriptive Statistics}

Table 2 presents the descriptive statistics for the ordered country pair year analyses. All variables are as defined in Appendix A.

\begin{tabular}{|c|c|c|c|c|c|c|}
\hline \multicolumn{7}{|c|}{ Country pair Observation Sample Descriptives } \\
\hline Variable & $\mathbf{N}$ & Mean & $\begin{array}{l}\text { Standard } \\
\text { Deviation }\end{array}$ & $\mathbf{p}(25)$ & Median & $\mathbf{p}(\mathbf{7 5})$ \\
\hline CBMA_Volume & 21,754 & 0.289 & 0.713 & 0.000 & 0.000 & 0.216 \\
\hline CBMA_Direction & 10,454 & 49.744 & 39.434 & 0.000 & 50.000 & 100.000 \\
\hline CBMA_Intermediary & 7,600 & 0.774 & 0.313 & 0.667 & 0.925 & 1.000 \\
\hline CBMA_Control & 7,600 & 0.113 & 0.244 & 0.000 & 0.000 & 0.100 \\
\hline CBMA_ErelRep & 21,754 & 1.573 & 4.341 & 0.000 & 0.000 & 0.641 \\
\hline Diff_Trate_CorpIncTax & 21,754 & 0.088 & 8.676 & -6.000 & 0.000 & 6.000 \\
\hline Diff_Trate_Dividends & 21,754 & 3.915 & 15.780 & -10.000 & 5.000 & 15.000 \\
\hline Aww_Tterr & 21,754 & 0.226 & 0.418 & 0.000 & 0.000 & 0.000 \\
\hline Aterr_Tww & 21,754 & 0.222 & 0.415 & 0.000 & 0.000 & 0.000 \\
\hline Aonly_CFC & 21,754 & 0.221 & 0.415 & 0.000 & 0.000 & 0.000 \\
\hline Tonly_CFC & 21,754 & 0.231 & 0.421 & 0.000 & 0.000 & 0.000 \\
\hline Aonly_ThinCap & 21,754 & 0.244 & 0.429 & 0.000 & 0.000 & 0.000 \\
\hline Tonly_ThinCap & 21,754 & 0.244 & 0.430 & 0.000 & 0.000 & 0.000 \\
\hline Aonly_TP & 21,754 & 0.147 & 0.354 & 0.000 & 0.000 & 0.000 \\
\hline Tonly_TP & 21,754 & 0.154 & 0.361 & 0.000 & 0.000 & 0.000 \\
\hline Tonly_FTC & 21,754 & 0.190 & 0.392 & 0.000 & 0.000 & 0.000 \\
\hline Aonly_FTC & 21,754 & 0.171 & 0.376 & 0.000 & 0.000 & 0.000 \\
\hline Tonly_IPBox & 21,754 & 0.121 & 0.326 & 0.000 & 0.000 & 0.000 \\
\hline Aonly_IPBox & 21,754 & 0.117 & 0.321 & 0.000 & 0.000 & 0.000 \\
\hline Diff_Xrate & 21,754 & 0.000 & 0.101 & -0.059 & 0.000 & 0.059 \\
\hline Diff_RealRI & 21,754 & -0.001 & 0.252 & -0.156 & -0.001 & 0.154 \\
\hline Diff_DisclosureIndex & 21,754 & -0.094 & 3.676 & -3.000 & 0.000 & 2.000 \\
\hline Diff_Anti_SelfDeal & 21,754 & -0.006 & 0.327 & -0.224 & -0.004 & 0.211 \\
\hline MaxTrade & 21,754 & 0.019 & 0.034 & 0.002 & 0.006 & 0.019 \\
\hline Diff_GDP & 21,754 & -0.047 & 1.683 & -1.229 & -0.038 & 1.120 \\
\hline Diff_GDPgrowth & 21,754 & 0.002 & 3.572 & -2.192 & 0.012 & 2.203 \\
\hline GCDist & 21,754 & 7.216 & 5.035 & 2.298 & 7.496 & 10.298 \\
\hline SameReligion & 21,754 & 0.606 & 0.489 & 0.000 & 1.000 & 1.000 \\
\hline SameLanguage & 21,754 & 0.038 & 0.191 & 0.000 & 0.000 & 0.000 \\
\hline
\end{tabular}




\section{Table 3: Determinants of Volume of Cross-Border M\&A}

Table 3 presents the results of the Ordinary Least Squares Regression of model (1) using CBMA_Volume as the dependent variable. Fixed effects are suppressed for brevity. All variables are defined in Appendix A. P-values are presented in parentheses in Column (2). *, **, and *** indicate significance at the $0.10,0.05$, and 0.01 levels, respectively (based on two-tailed tests).

\begin{tabular}{|c|c|c|c|c|}
\hline \multicolumn{5}{|c|}{ Panel A } \\
\hline \multirow[b]{2}{*}{ VARIABLES } & Pred. & $(1)$ & & (2) \\
\hline & Sign & Coefficient & & $\mathrm{p}$-value \\
\hline Diff_Trate_CorpIncTax & + & $0.003 * *$ & & $(0.020)$ \\
\hline Trate_Dividends & - & $-0.003 * * *$ & & $(0.001)$ \\
\hline$A w w \_T t e r r$ & - & -0.016 & & $(0.518)$ \\
\hline Aterr_Tww & + & 0.000 & & $(1.000)$ \\
\hline Aonly_CFC & - & $-0.227 * * *$ & & $(0.000)$ \\
\hline Tonly_CFC & + & 0.002 & & $(0.911)$ \\
\hline Aonly_ThinCap & $?$ & 0.022 & & $(0.340)$ \\
\hline Tonly_ThinCap & $?$ & -0.010 & & $(0.679)$ \\
\hline Aonly_TP & $?$ & $-0.149 * * *$ & & $(0.000)$ \\
\hline Tonly_TP & $?$ & 0.004 & & $(0.869)$ \\
\hline Tonly_FTC & - & -0.027 & & $(0.487)$ \\
\hline Aonly_FTC & + & -0.002 & & $(0.946)$ \\
\hline Tonly_IPBox & $?$ & -0.029 & & $(0.223)$ \\
\hline Aonly_IPBox & $?$ & -0.064 & & $(0.120)$ \\
\hline Diff_Xrate & + & 0.035 & & $(0.196)$ \\
\hline Diff_RealRI & - & -0.008 & & $(0.583)$ \\
\hline Diff_DisclosureIndex & + & $-0.011 * *$ & & $(0.024)$ \\
\hline Diff_Anti_SelfDeal & - & 0.055 & & $(0.410)$ \\
\hline MaxTrade & + & $8.415 * * *$ & & $(0.000)$ \\
\hline Diff_GDP & + & -0.010 & & $(0.290)$ \\
\hline Diff_GDPgrowth & - & $-0.005 * * *$ & & $(0.000)$ \\
\hline GCDist & - & $-0.021 * * *$ & & $(0.000)$ \\
\hline SameReligion & + & $0.078 * * *$ & & $(0.001)$ \\
\hline SameLanguage & + & $0.691 * * *$ & & $(0.000)$ \\
\hline Observations & & & 21,754 & \\
\hline Adjusted R-Squared & & & 0.342 & \\
\hline Year Fixed Effects & & & YES & \\
\hline Acquirer Country Fixed & & & YES & \\
\hline Robust SE Clustered by & y-Pair & & YES & \\
\hline
\end{tabular}


Table 3: Determinants of Volume of Cross-Border M\&A (cont.)

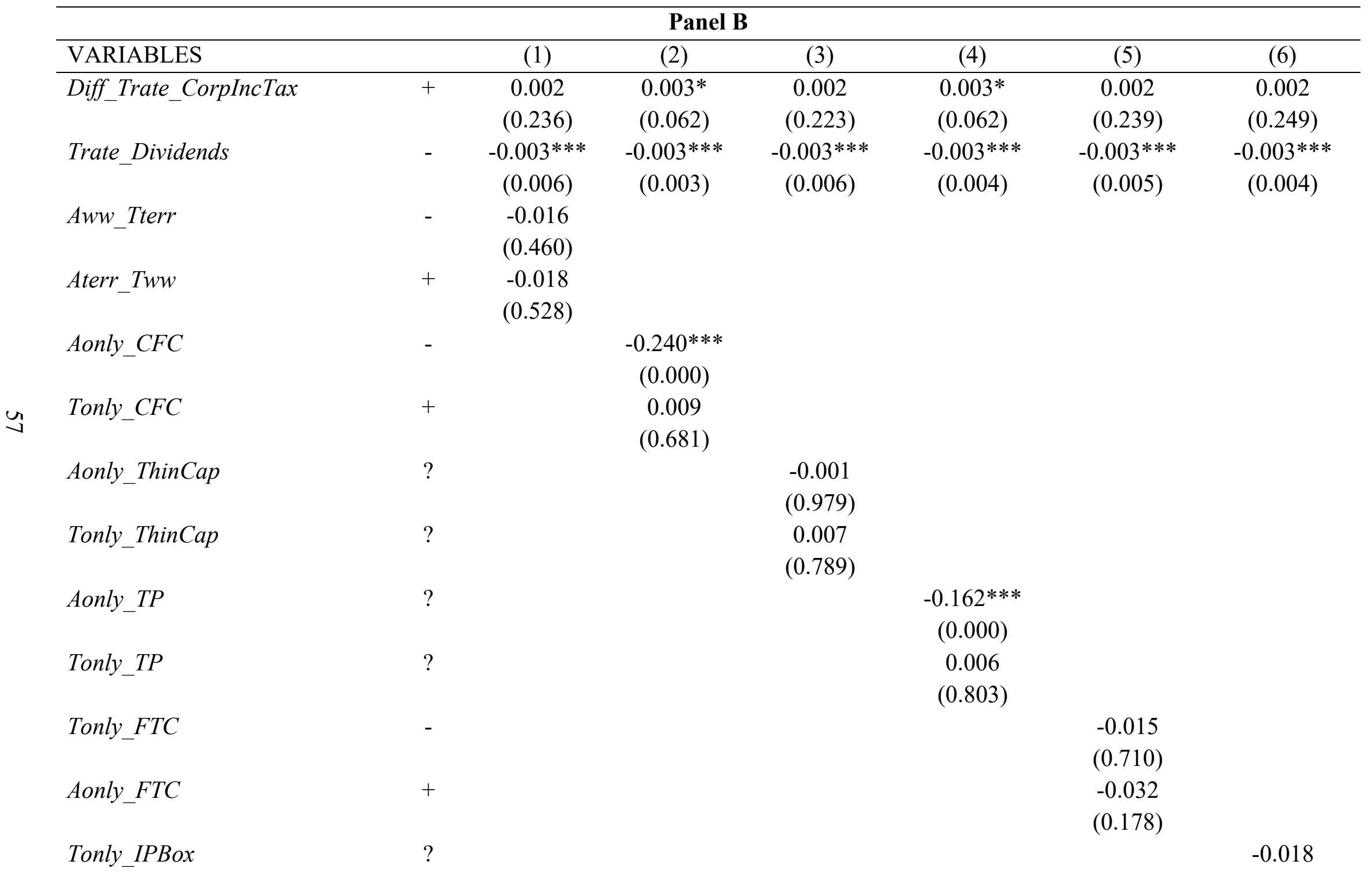




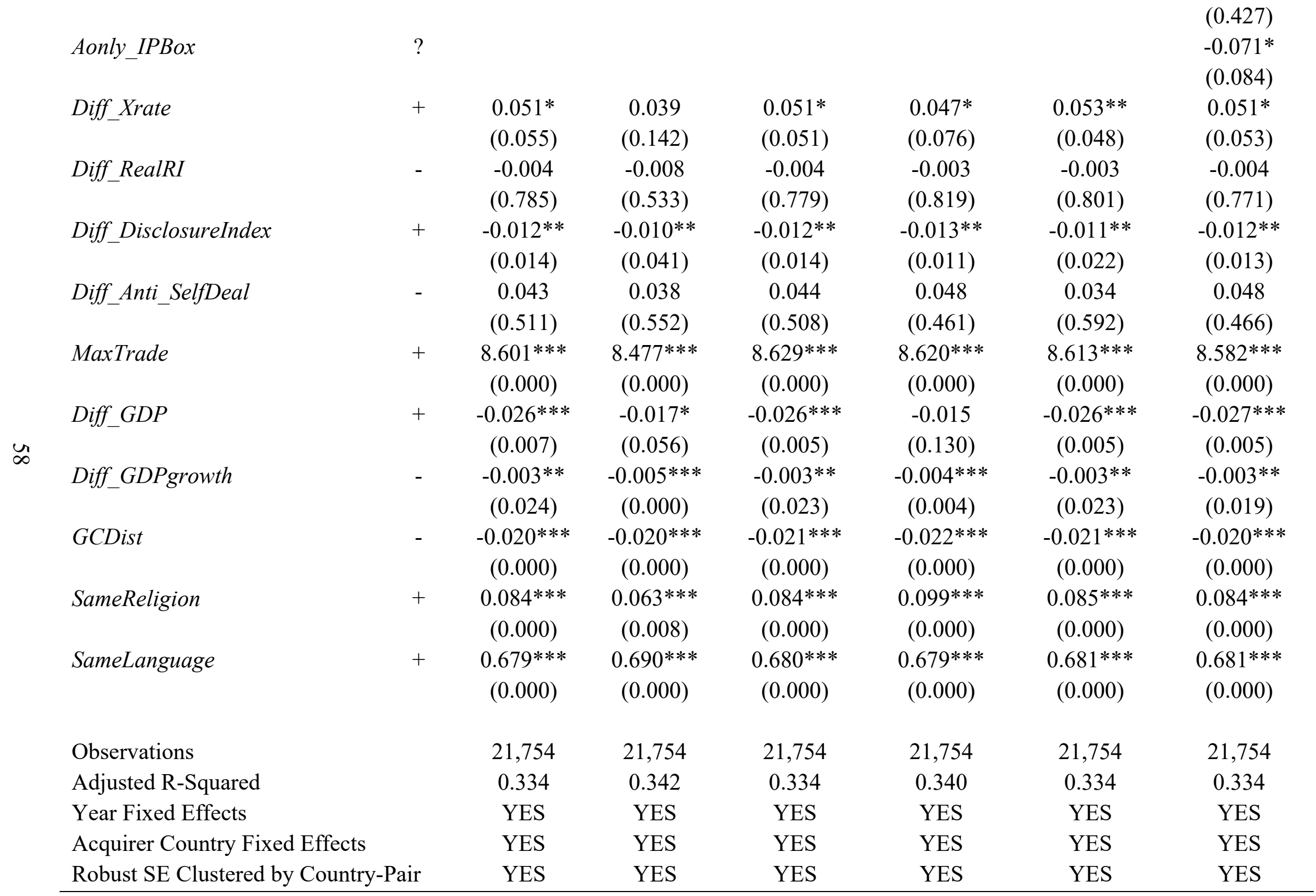




\section{Table 4: Determinants of Volume of Cross-Border M\&A by Acquirer Country Tax Regime}

Table 4 presents the results of the Ordinary Least Squares Regression of model (1) using Seemingly Unrelated Regression, where each observation is an ordered country pair year. Column (1) includes all observations in which the acquirer country is worldwide, while Column (2) includes all observations in which the acquirer country is territorial. Column (3) presents t-tests of differences across the two specifications. Fixed effects are suppressed for brevity. All variables are defined in Appendix A. P-values are presented in parentheses below each coefficient. *, **, and $* * *$ indicate significance at the $0.10,0.05$, and 0.01 levels, respectively (based on two-tailed tests).

\begin{tabular}{|c|c|c|c|}
\hline & $\begin{array}{l}\text { (1) } \\
\text { Worldwide }\end{array}$ & $\begin{array}{c}(2) \\
\text { Territorial }\end{array}$ & (3) \\
\hline VARIABLES & & & Difference \\
\hline Diff_Trate_CorpIncTax & $\begin{array}{c}0.002 * * \\
(0.049)\end{array}$ & $\begin{array}{c}0.004 * * * \\
(0.000)\end{array}$ & $\begin{array}{c}-0.002 \\
(0.4598)\end{array}$ \\
\hline Trate_Dividends & $\begin{array}{l}-0.002 \\
(0.178)\end{array}$ & $\begin{array}{c}-0.004 * * \\
(0.013)\end{array}$ & $\begin{array}{c}0.002 \\
(0.2872)\end{array}$ \\
\hline$T \_W W$ & $\begin{array}{c}0.003 \\
(0.824)\end{array}$ & $\begin{array}{c}0.011 \\
(0.490)\end{array}$ & $\begin{array}{c}-0.008 \\
(0.8318)\end{array}$ \\
\hline Aonly_CFC & $\begin{array}{c}-0.164 * * * \\
(0.000)\end{array}$ & $\begin{array}{c}-0.208 * * * \\
(0.000)\end{array}$ & $\begin{array}{c}0.044 \\
(0.6383)\end{array}$ \\
\hline Tonly_CFC & $\begin{array}{c}-0.014 \\
(0.308)\end{array}$ & $\begin{array}{c}0.002 \\
(0.903)\end{array}$ & $\begin{array}{c}-0.016 \\
(0.6981)\end{array}$ \\
\hline Aonly_ThinCap & $\begin{array}{c}0.017 \\
(0.277)\end{array}$ & $\begin{array}{c}0.022 \\
(0.163)\end{array}$ & $\begin{array}{c}-0.005 \\
(0.9052)\end{array}$ \\
\hline Tonly_ThinCap & $\begin{array}{l}-0.003 \\
(0.824)\end{array}$ & $\begin{array}{c}0.014 \\
(0.439)\end{array}$ & $\begin{array}{c}-0.017 \\
(0.7187)\end{array}$ \\
\hline Aonly_TP & $\begin{array}{c}-0.137 * * * \\
(0.000)\end{array}$ & $\begin{array}{c}-0.170 * * * \\
(0.000)\end{array}$ & $\begin{array}{c}0.033 \\
(0.4520)\end{array}$ \\
\hline Tonly_TP & $\begin{array}{c}0.018 \\
(0.387)\end{array}$ & $\begin{array}{l}-0.010 \\
(0.736)\end{array}$ & $\begin{array}{c}0.028 \\
(0.5612)\end{array}$ \\
\hline Tonly_FTC & $\begin{array}{c}-0.041 \\
(0.200)\end{array}$ & $\begin{array}{l}-0.025 \\
(0.320)\end{array}$ & $\begin{array}{c}-0.016 \\
(0.7931)\end{array}$ \\
\hline Aonly_FTC & $\begin{array}{c}-0.004 \\
(0.824)\end{array}$ & $\begin{array}{l}-0.021 \\
(0.274)\end{array}$ & $\begin{array}{c}0.017 \\
(0.7161)\end{array}$ \\
\hline Tonly_IPBox & $\begin{array}{l}-0.022 \\
(0.204)\end{array}$ & $\begin{array}{l}-0.022 \\
(0.239)\end{array}$ & $\begin{array}{c}0.000 \\
(0.9985)\end{array}$ \\
\hline Aonly_IPBox & $\begin{array}{c}-0.075 \\
(0.183)\end{array}$ & $\begin{array}{c}-0.001 \\
(0.966)\end{array}$ & $\begin{array}{c}-0.074 \\
(0.4266)\end{array}$ \\
\hline
\end{tabular}




\begin{tabular}{|c|c|c|c|}
\hline Diff_Xrate & $\begin{array}{c}0.077 \\
(0.111)\end{array}$ & $\begin{array}{c}-0.019 \\
(0.759)\end{array}$ & $\begin{array}{c}0.096 * \\
(0.0767)\end{array}$ \\
\hline Diff_RealRI & $\begin{array}{l}-0.000 \\
(1.000)\end{array}$ & $\begin{array}{c}-0.017 \\
(0.499)\end{array}$ & $\begin{array}{c}0.017 \\
(0.5281)\end{array}$ \\
\hline Diff_DisclosureIndex & $\begin{array}{l}-0.006 * \\
(0.056)\end{array}$ & $\begin{array}{c}-0.014 * * * \\
(0.000)\end{array}$ & $\begin{array}{c}0.008 \\
(0.3532)\end{array}$ \\
\hline Diff_Anti_SelfDeal & $\begin{array}{c}-0.122 * * * \\
(0.001)\end{array}$ & $\begin{array}{c}0.134 * * * \\
(0.001)\end{array}$ & $\begin{array}{c}-0.256^{* *} \\
(0.0313)\end{array}$ \\
\hline MaxTrade & $\begin{array}{c}4.295 * * * \\
(0.000)\end{array}$ & $\begin{array}{c}10.668 * * * \\
(0.000)\end{array}$ & $\begin{array}{c}-6.373 * * * \\
(0.0001)\end{array}$ \\
\hline Diff_GDP & $\begin{array}{c}0.018 * * * \\
(0.001)\end{array}$ & $\begin{array}{c}-0.018 * * * \\
(0.006)\end{array}$ & $\begin{array}{l}-0.036 * * \\
(0.0344)\end{array}$ \\
\hline Diff_GDPgrowth & $\begin{array}{c}-0.003 \\
(0.134)\end{array}$ & $\begin{array}{c}-0.007 * * * \\
(0.001)\end{array}$ & $\begin{array}{c}0.004 * \\
(0.0786)\end{array}$ \\
\hline GCDist & $\begin{array}{c}-0.022 * * * \\
(0.000)\end{array}$ & $\begin{array}{c}-0.020 * * * \\
(0.000)\end{array}$ & $\begin{array}{c}-0.002 \\
(0.7217)\end{array}$ \\
\hline SameReligion & $\begin{array}{c}0.064 * * * \\
(0.000)\end{array}$ & $\begin{array}{c}0.082 * * * \\
(0.000)\end{array}$ & $\begin{array}{c}-0.018 \\
(0.7050)\end{array}$ \\
\hline SameLanguage & $\begin{array}{c}0.682 * * * \\
(0.000)\end{array}$ & $\begin{array}{c}0.730 * * * \\
(0.000)\end{array}$ & $\begin{array}{c}-0.048 \\
(0.8047)\end{array}$ \\
\hline Observations & 9,253 & 12,501 & \\
\hline Adjusted R-Squared & 0.275 & 0.387 & \\
\hline Year Fixed Effects & YES & YES & \\
\hline Acquirer Country Fixed Effects & YES & YES & \\
\hline
\end{tabular}




\section{Table 5: Determinants of Direction of Cross-Border M\&A}

Table 5 presents the results of the Ordinary Least Squares Regression of model (1) using CBMA_Direction as the dependent variable. Each observation is an ordered country pair year. Fixed effects are suppressed for brevity. All variables are defined in Appendix A. P-values are presented in parentheses in Column (2). $* * *$, and $* * *$ indicate significance at the $0.10,0.05$, and 0.01 levels, respectively (based on two-tailed tests).

\begin{tabular}{|c|c|c|c|c|}
\hline \multicolumn{5}{|c|}{ Panel A } \\
\hline \multirow[b]{2}{*}{ VARIABLES } & Pred. & $(1)$ & & $(2)$ \\
\hline & Sign & Coefficient & & p-value \\
\hline Diff_Trate_CorpIncTax & + & $0.740 * * *$ & & $(0.000)$ \\
\hline Diff_Trate_Dividends & - & $-0.246 * * *$ & & $(0.000)$ \\
\hline Aww_Tterr & - & $-2.793^{*}$ & & $(0.061)$ \\
\hline Aterr_Tww & + & 1.282 & & $(0.336)$ \\
\hline Aonly_CFC & - & $-7.457 * * *$ & & $(0.000)$ \\
\hline Tonly_CFC & + & $7.748 * * *$ & & $(0.000)$ \\
\hline Aonly_ThinCap & $?$ & $-7.557 * * *$ & & $(0.000)$ \\
\hline Tonly_ThinCap & $?$ & $7.530 * * *$ & & $(0.000)$ \\
\hline Aonly_TP & $?$ & $3.094 * *$ & & $(0.021)$ \\
\hline Tonly_TP & $?$ & -2.468 & & $(0.274)$ \\
\hline Tonly_FTC & - & -2.567 & & $(0.383)$ \\
\hline Aonly_FTC & + & $3.086^{* *}$ & & $(0.035)$ \\
\hline Tonly_IPBox & $?$ & 0.208 & & $(0.863)$ \\
\hline Aonly_IPBox & $?$ & 0.000 & & $(1.000)$ \\
\hline Diff_Xrate & $?$ & $-5.288^{*}$ & & $(0.096)$ \\
\hline Diff_RealRI & $?$ & $4.890 * * *$ & & $(0.001)$ \\
\hline Diff_DisclosureIndex & $?$ & $-1.223 * * *$ & & $(0.000)$ \\
\hline Diff_Anti_SelfDeal & $?$ & $17.109 * * *$ & & $(0.000)$ \\
\hline MaxTrade & + & 18.556 & & $(0.167)$ \\
\hline Diff_GDP & + & $12.009 * * *$ & & $(0.000)$ \\
\hline Diff_GDPgrowth & - & 0.167 & & $(0.184)$ \\
\hline Observations & & & 10,454 & \\
\hline Adjusted R-Squared & & & 0.377 & \\
\hline Year Fixed Effects & & & YES & \\
\hline Acquirer Country Fixed & & & YES & \\
\hline Robust SE Clustered by & $y$-Pair & & YES & \\
\hline
\end{tabular}


Table 5: Determinants of Direction of Cross-Border M\&A (cont.)

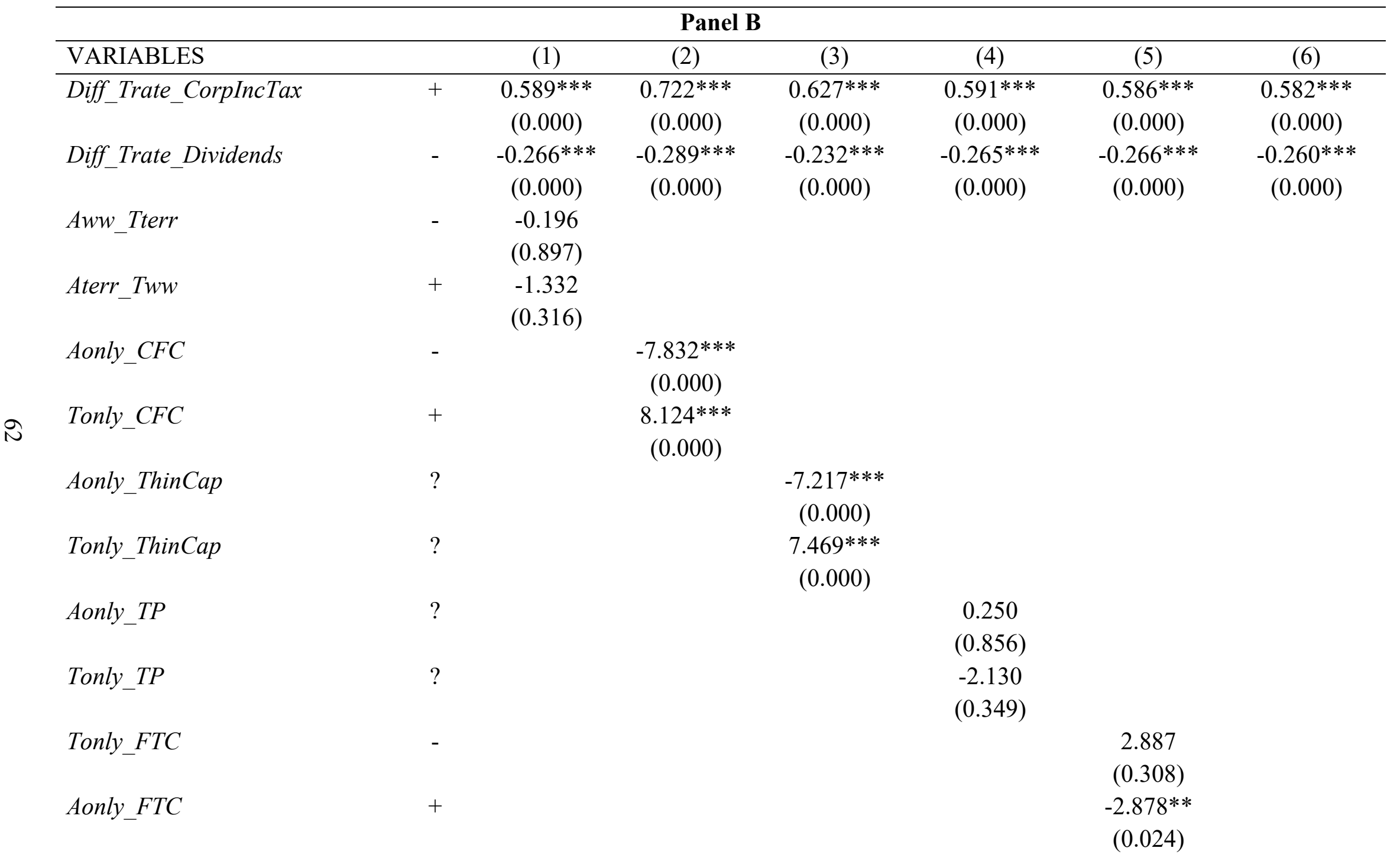


Tonly_IPBox

Aonly_IPBox

?

Diff_Xrate

Diff_RealRI

Diff_DisclosureIndex

Diff_Anti_SelfDeal

MaxTrade

๘) Diff_GDP

Diff_GDPgrowth

Observations

Adjusted R-Squared

Year Fixed Effects

Acquirer Country Fixed Effects

Robust SE Clustered by Country-Pair
$-1.975$

(0.121)

1.272

(0.447)

$-4.302 \quad-5.236^{*}$

\begin{abstract}
$-4.785$
\end{abstract}
$-4.066$

$-4.054$

$-4.307$

(0.172)

(0.097)

(0.129)

$(0.195)$

(0.197)

$?$

$5.760 * * *$

$5.534 * * *$

$5.043 * * *$

$5.818 * * *$

$5.747 * * *$

(0.171)

(0.000)

(0.000)

(0.001)

(0.000)

(0.000)

(0.000)

$-1.133 * * *$

$-1.544 * * *$

$-1.457 * * *$

(0.000)

$?$

$20.471 * * * \quad 18.028 * * *$

(0.000)

(0.000)

(0.000)

$19.822 * * *$

$20.529 * * *$

$-1.373 * * *$

(0.000)

(0.000)

$20.038 * * *$

(0.000)

23.122*

(0.099)

(0.160)

$+\quad 11.311 * * *$

(0.117)

22.430

(0.103)

(0.000)

$0.438 * * *$
$(0.000)$

$12.194 * * *$
$(0.000)$

$11.307^{* * *}$

$(0.124)$

$11.182 * * *$

$11.082 * * *$

(0.000)

$0.293 * *$

(0.020)

(0.000)

$0.450 * * *$

(0.000)

(0.000)

$0.435 * * *$

(0.001)

$5.723 * * *$

(0.000)

$-1.507 * * *$

(0.000)

$21.527 * * *$

(0.000)

21.846

(0.126)

$11.036^{* * *}$

(0.000)

(0.035)

10,454

0.370

YES

10,454

0.360

10,454

0.361

YES

YES

YES

YES

YES
$0.456^{* * *}$

(0.000)

10,454

0.361

YES

YES

YES 


\section{Table 6: Determinants of Direction of Cross-Border M\&A by Acquirer Country Tax Regime}

Table 6 presents the results of the Ordinary Least Squares Regression of model (1) using Seemingly Unrelated Regression, where each observation is an ordered country pair year. Column (1) includes all observations in which the acquirer country is worldwide, while Column (2) includes all observations in which the acquirer country is territorial. Column (3) presents t-tests of differences across the two specifications. Fixed effects are suppressed for brevity. All variables are defined in Appendix A. P-values are presented in parentheses below each coefficient. *,**, and $* * *$ indicate significance at the $0.10,0.05$, and 0.01 levels, respectively (based on two-tailed tests).

\begin{tabular}{|c|c|c|c|}
\hline & $\begin{array}{c}\text { (1) } \\
\text { Worldwide }\end{array}$ & $\begin{array}{c}(2) \\
\text { Territorial }\end{array}$ & (3) \\
\hline VARIABLES & $C B M A$ & ctionet & Difference \\
\hline Diff_Trate_CorpIncTax & $\begin{array}{c}0.670 * * * \\
(0.000)\end{array}$ & $\begin{array}{c}0.741 * * * \\
(0.000)\end{array}$ & $\begin{array}{c}-0.071 \\
(0.6559)\end{array}$ \\
\hline Diff_Trate_Dividends & $\begin{array}{c}-0.196 * * * \\
(0.002)\end{array}$ & $\begin{array}{c}-0.260 * * * \\
(0.000)\end{array}$ & $\begin{array}{c}0.064 \\
(0.5423)\end{array}$ \\
\hline$T \_W W$ & $\begin{array}{c}3.156 * * \\
(0.023)\end{array}$ & $\begin{array}{l}-0.509 \\
(0.647)\end{array}$ & $\begin{array}{c}3.665 \\
(0.1195)\end{array}$ \\
\hline Aonly_CFC & $\begin{array}{c}-8.163 * * * \\
(0.000)\end{array}$ & $\begin{array}{c}-7.178 * * * \\
(0.000)\end{array}$ & $\begin{array}{c}-0.985 \\
(0.7326)\end{array}$ \\
\hline Tonly_CFC & $\begin{array}{c}7.856 * * * \\
(0.000)\end{array}$ & $\begin{array}{c}7.353 * * * \\
(0.000)\end{array}$ & $\begin{array}{c}0.503 \\
(0.8474)\end{array}$ \\
\hline Aonly_ThinCap & $\begin{array}{c}-7.098 * * * \\
(0.000)\end{array}$ & $\begin{array}{c}-7.880 * * * \\
(0.000)\end{array}$ & $\begin{array}{c}0.782 \\
(0.7727)\end{array}$ \\
\hline Tonly_ThinCap & $\begin{array}{c}9.474 * * * \\
(0.000)\end{array}$ & $\begin{array}{c}6.174 * * * \\
(0.000)\end{array}$ & $\begin{array}{c}3.3 \\
(0.1817)\end{array}$ \\
\hline Aonly_TP & $\begin{array}{c}3.704 * * \\
(0.048)\end{array}$ & $\begin{array}{c}3.098 * * \\
(0.013)\end{array}$ & $\begin{array}{c}0.606 \\
(0.8336)\end{array}$ \\
\hline Tonly_TP & $\begin{array}{l}-3.187 \\
(0.176)\end{array}$ & $\begin{array}{l}-4.247 \\
(0.145)\end{array}$ & $\begin{array}{c}1.06 \\
(0.8210)\end{array}$ \\
\hline Tonly_FTC & $\begin{array}{c}16.105 * * * \\
(0.004)\end{array}$ & $\begin{array}{l}-3.552 * \\
(0.053)\end{array}$ & $\begin{array}{l}19.657 * * \\
(0.0226)\end{array}$ \\
\hline Aonly_FTC & $\begin{array}{c}3.827 * * \\
(0.017)\end{array}$ & $\begin{array}{c}2.518 * * \\
(0.048)\end{array}$ & $\begin{array}{c}1.309 \\
(0.6504)\end{array}$ \\
\hline Tonly_IPBox & $\begin{array}{l}-0.457 \\
(0.781)\end{array}$ & $\begin{array}{c}0.348 \\
(0.773)\end{array}$ & $\begin{array}{c}-0.805 \\
(0.9336)\end{array}$ \\
\hline Aonly_IPBox & $\begin{array}{l}-0.191 \\
(0.973)\end{array}$ & $\begin{array}{c}0.357 \\
(0.810)\end{array}$ & $\begin{array}{c}-0.548 \\
(0.7463)\end{array}$ \\
\hline
\end{tabular}




\begin{tabular}{lccc} 
Diff_Xrate & -2.763 & -6.202 & 3.439 \\
Diff_RealRI & $(0.584)$ & $(0.150)$ & $(0.5938)$ \\
& 2.604 & $5.994 * * *$ & -3.39 \\
Diff_DisclosureIndex & $(0.255)$ & $(0.003)$ & $(0.2665)$ \\
& $-1.552^{* * *}$ & $-1.010^{* * *}$ & -0.542 \\
Diff_Anti_SelfDeal & $(0.000)$ & $(0.000)$ & $(0.3717)$ \\
& $15.844^{* * *}$ & $16.637 * * *$ & -0.793 \\
MaxTrade & $(0.000)$ & $(0.000)$ & $(0.8976)$ \\
& -20.272 & $39.435^{* * *}$ & $-59.707 * *$ \\
Diff_GDP & $(0.215)$ & $(0.001)$ & $(0.0242)$ \\
& $11.456 * * *$ & $12.875 * * *$ & -1.419 \\
Diff_GDPgrowth & $(0.000)$ & $(0.000)$ & $(0.2442)$ \\
& $0.339 *$ & 0.006 & 0.333 \\
& $(0.085)$ & $(0.971)$ & $(0.1959)$ \\
Observations & & & \\
Adjusted R-Squared & 3,967 & 6,487 & \\
Year Fixed Effects & 0.362 & 0.378 & \\
Acquirer Country Fixed Effects & YES & YES & \\
\hline
\end{tabular}




\section{Table 7: Descriptive Statistics}

Table 7 presents the descriptive statistics for the country year analyses. All variables are as defined in Appendix A.

\begin{tabular}{lcccccc}
\hline Country year Observation Sample Descriptives \\
Variable & $\mathbf{N}$ & Mean & $\begin{array}{c}\text { Standard } \\
\text { Deviation }\end{array}$ & $\mathbf{p}(\mathbf{2 5})$ & Median & $\mathbf{p ( 7 5 )}$ \\
\hline CL_TVolume & 469.000 & 1.366 & 1.646 & 0.535 & 0.830 & 1.471 \\
CL_AVolume & 469.000 & 1.139 & 3.221 & 0.267 & 0.486 & 0.875 \\
CL_Direction & 469.000 & 0.392 & 0.196 & 0.221 & 0.403 & 0.554 \\
Trate_CorpIncTax & 469.000 & 25.089 & 6.166 & 20.000 & 25.000 & 30.000 \\
WW & 469.000 & 0.469 & 0.500 & 0.000 & 0.000 & 1.000 \\
CFC & 469.000 & 0.333 & 0.472 & 0.000 & 0.000 & 1.000 \\
ThinCap & 469.000 & 0.497 & 0.501 & 0.000 & 0.000 & 1.000 \\
TP & 469.000 & 0.821 & 0.384 & 1.000 & 1.000 & 1.000 \\
FTC & 469.000 & 0.774 & 0.419 & 1.000 & 1.000 & 1.000 \\
IPBox & 469.000 & 0.136 & 0.344 & 0.000 & 0.000 & 0.000 \\
Xrate & 469.000 & 0.003 & 0.098 & -0.061 & 0.011 & 0.064 \\
RealRI & 469.000 & 0.092 & 0.267 & -0.041 & 0.109 & 0.251 \\
DisclosureIndex & 469.000 & 6.533 & 2.613 & 5.000 & 7.000 & 8.000 \\
Anti_SelfDeal & 469.000 & 0.467 & 0.231 & 0.283 & 0.429 & 0.642 \\
GDP & 469.000 & 9.749 & 1.202 & 8.964 & 10.034 & 10.746 \\
GDPgrowth & 469.000 & 1.714 & 3.063 & 0.250 & 1.700 & 3.607
\end{tabular}




\section{Table 8: Determinants of Volume of Cross-Border M\&A}

Table 8 presents the results of the Ordinary Least Squares Regression of model (3) using CL_TVolume as the dependent variable. Each observation is a country year. Fixed effects are suppressed for brevity. All variables are defined in Appendix A. P-values are presented in parentheses in Column (2). *,**, and *** indicate significance at the $0.10,0.05$, and 0.01 levels, respectively (based on two-tailed tests).

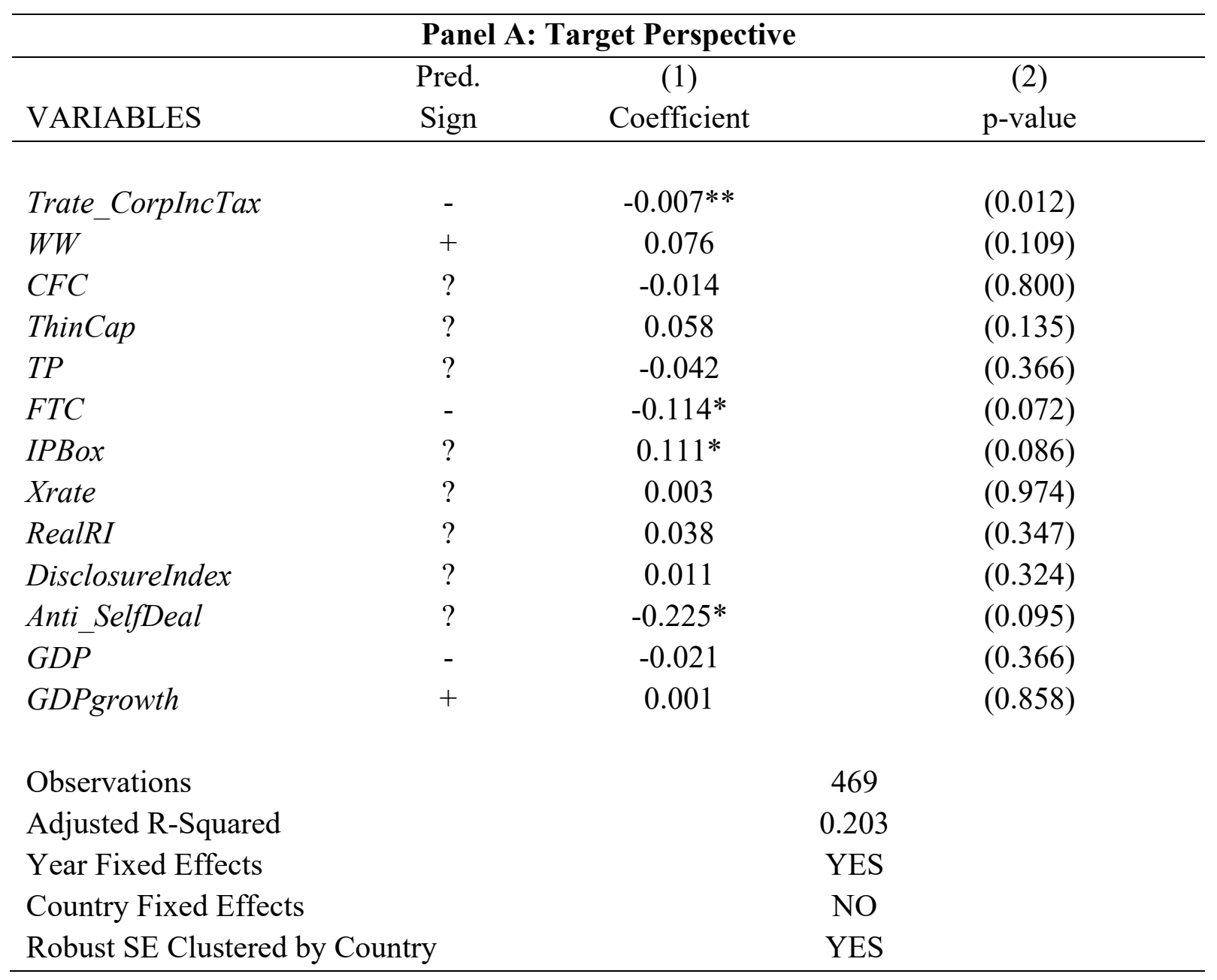




\section{Table 8: Determinants of Volume of Cross-Border M\&A (cont.)}

Table 8 presents the results of the Ordinary Least Squares Regression of model (3) using CL_AVolume as the dependent variable. Each observation is a country year. Fixed effects are suppressed for brevity. All variables are defined in Appendix A. P-values are presented in parentheses in Column (2). *,*, and *** indicate significance at the $0.10,0.05$, and 0.01 levels, respectively (based on two-tailed tests).

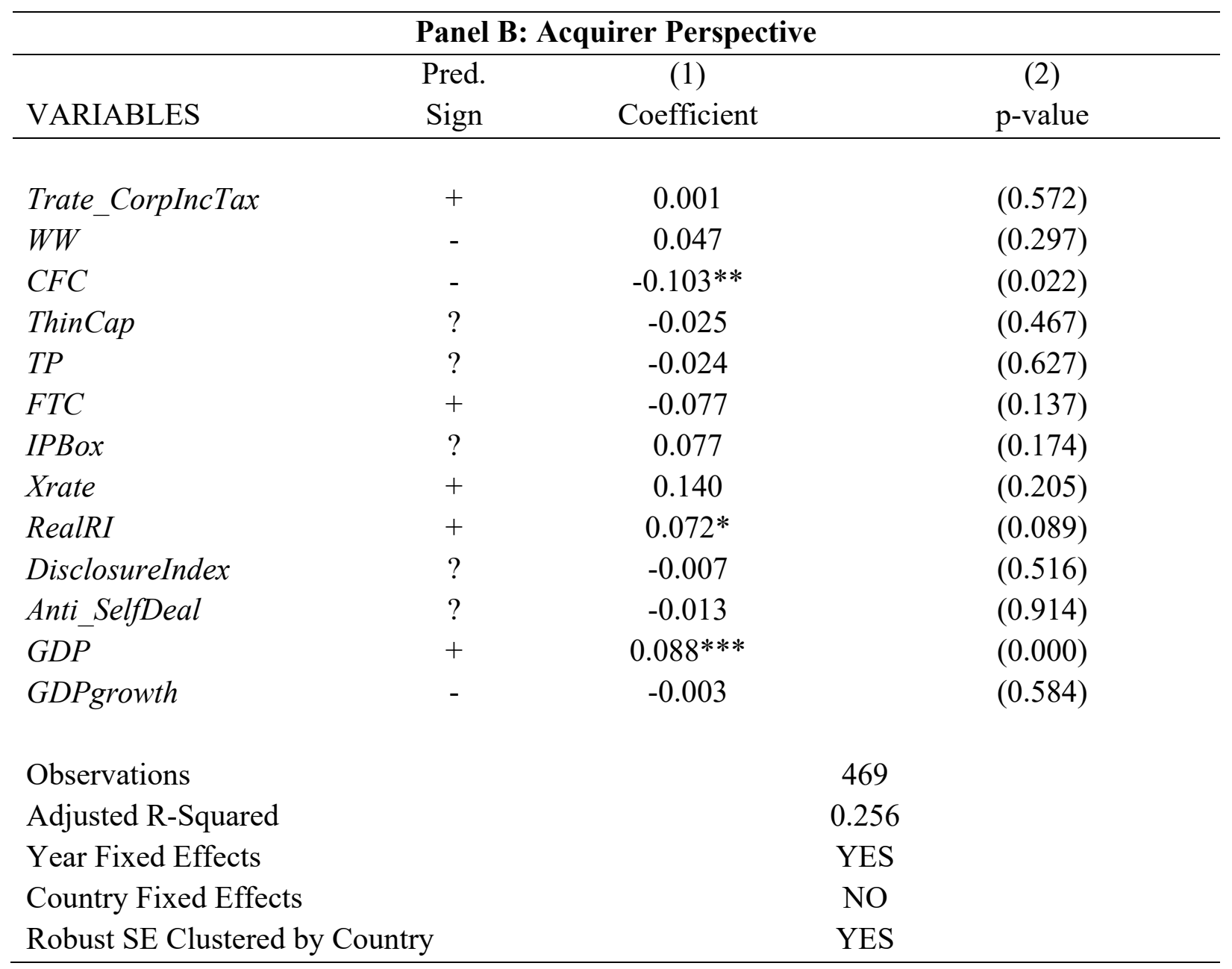




\section{Table 9: Determinants of Direction of Cross-Border M\&A}

Table 9 presents the results of the Ordinary Least Squares Regression of model (3) using CL_Direction as the dependent variable. Each observation is a country year. Fixed effects are suppressed for brevity. All variables are defined in Appendix A. P-values are presented in parentheses in Column (2). *,*, and *** indicate significance at the $0.10,0.05$, and 0.01 levels, respectively (based on two-tailed tests).

\begin{tabular}{|c|c|c|c|}
\hline VARIABLES & $\begin{array}{l}\text { Pred. } \\
\text { Sign }\end{array}$ & $\begin{array}{c}(1) \\
\text { Coefficient }\end{array}$ & $\begin{array}{c}(2) \\
\text { p-value }\end{array}$ \\
\hline Trate_CorpIncTax & + & $0.008 * * *$ & $(0.004)$ \\
\hline$W W$ & - & -0.004 & $(0.903)$ \\
\hline$C F C$ & - & $-0.104 * * *$ & $(0.004)$ \\
\hline ThinCap & $?$ & $-0.061 * *$ & $(0.046)$ \\
\hline$T P$ & $?$ & 0.025 & $(0.469)$ \\
\hline FTC & + & 0.016 & $(0.709)$ \\
\hline IPBox & $?$ & -0.005 & $(0.896)$ \\
\hline Xrate & + & 0.143 & $(0.268)$ \\
\hline RealRI & + & 0.035 & $(0.301)$ \\
\hline DisclosureIndex & $?$ & -0.012 & $(0.196)$ \\
\hline Anti_SelfDeal & $?$ & $0.164 *$ & $(0.095)$ \\
\hline$G D P$ & + & $0.119 * * *$ & $(0.000)$ \\
\hline GDPgrowth & - & -0.001 & $(0.620)$ \\
\hline Observations & \multicolumn{3}{|c|}{469} \\
\hline Adjusted R-Squared & \multicolumn{3}{|c|}{0.528} \\
\hline Year Fixed Effects & \multicolumn{3}{|c|}{ YES } \\
\hline Country Fixed Effec & \multicolumn{3}{|c|}{ NO } \\
\hline Robust SE Clusterec & \multicolumn{3}{|c|}{ YES } \\
\hline
\end{tabular}




\section{Table 10: Determinants of Obtaining Control in Cross-Border M\&A}

Table 10 presents the results of the Ordinary Least Squares Regression of model (2) using CBMA_Control as the dependent variable. Each observation is an ordered country pair year. Fixed effects are suppressed for brevity. All variables are defined in Appendix A. P-values are presented in parentheses in Column (2). *,**, and *** indicate significance at the $0.10,0.05$, and 0.01 levels, respectively (based on two-tailed tests).

\begin{tabular}{|c|c|c|}
\hline VARIABLES & $\begin{array}{c}(1) \\
\text { Coefficient }\end{array}$ & $\begin{array}{c}(2) \\
\text { p-value }\end{array}$ \\
\hline Diff_Trate_CorpIncTax & $0.001 * *$ & $(0.050)$ \\
\hline Diff_Trate_Dividends & -0.000 & $(0.517)$ \\
\hline$A w w \_$Tterr & -0.001 & $(0.946)$ \\
\hline Aterr_Tww & -0.015 & $(0.223)$ \\
\hline Aonly_CFC & $-0.042 * * *$ & $(0.001)$ \\
\hline Tonly_CFC & $0.047 * * *$ & $(0.000)$ \\
\hline Aonly_ThinCap & -0.011 & $(0.358)$ \\
\hline Tonly_ThinCap & $0.029 * * *$ & $(0.010)$ \\
\hline Aonly_TP & -0.018 & $(0.183)$ \\
\hline Tonly_TP & -0.014 & $(0.643)$ \\
\hline Tonly_FTC & -0.030 & $(0.219)$ \\
\hline Aonly_FTC & $0.039 * * *$ & $(0.003)$ \\
\hline Tonly_IPBox & 0.019 & $(0.134)$ \\
\hline Aonly_IPBox & -0.012 & $(0.411)$ \\
\hline Diff_Xrate & 0.001 & $(0.970)$ \\
\hline Diff_RealRI & 0.004 & $(0.836)$ \\
\hline Diff_DisclosureIndex & 0.000 & $(0.972)$ \\
\hline Diff_Anti_SelfDeal & -0.011 & $(0.689)$ \\
\hline MaxTrade & -0.134 & $(0.252)$ \\
\hline Diff_GDP & $-0.019 * * *$ & $(0.000)$ \\
\hline Diff_GDPgrowth & -0.000 & $(0.819)$ \\
\hline GCDist & -0.002 & $(0.141)$ \\
\hline SameReligion & $0.029 *$ & $(0.051)$ \\
\hline SameLanguage & 0.023 & $(0.190)$ \\
\hline Observations & \multicolumn{2}{|c|}{7,600} \\
\hline Adjusted R-Squared & \multicolumn{2}{|c|}{0.060} \\
\hline Year Fixed Effects & \multicolumn{2}{|c|}{ YES } \\
\hline Acquirer Country Fixed Effects & \multicolumn{2}{|c|}{ YES } \\
\hline Robust SE Clustered by Country & \multicolumn{2}{|c|}{ YES } \\
\hline
\end{tabular}




\section{Table 11: Determinants of the use of an Intermediary in Cross-Border M\&A}

Table 11 presents the results of the Ordinary Least Squares Regression of model (2) using $C B M A$ Intermediary as the dependent variable. Each observation is an ordered country pair year. Fixed effects are suppressed for brevity. All variables are defined in Appendix A. P-values are presented in parentheses in Column (2).*,**, and *** indicate significance at the $0.10,0.05$, and 0.01 levels, respectively (based on two-tailed tests).

\begin{tabular}{|c|c|c|}
\hline VARIABLES & $\begin{array}{c}\text { (1) } \\
\text { Coefficient }\end{array}$ & $\begin{array}{c}(2) \\
\text { p-value }\end{array}$ \\
\hline Diff_Trate_CorpIncTax & 0.000 & $(0.390)$ \\
\hline Diff_Trate_Dividends & 0.000 & $(0.611)$ \\
\hline Aww_Tterr & 0.017 & $(0.108)$ \\
\hline Aterr_Tww & $-0.020 * *$ & $(0.031)$ \\
\hline Aonly_CFC & -0.003 & $(0.656)$ \\
\hline Tonly_CFC & -0.015 & $(0.108)$ \\
\hline Aonly_ThinCap & $-0.014^{*}$ & $(0.094)$ \\
\hline Tonly_ThinCap & -0.001 & $(0.880)$ \\
\hline Aonly_TP & 0.013 & $(0.210)$ \\
\hline Tonly_TP & -0.010 & $(0.569)$ \\
\hline Tonly_FTC & -0.022 & $(0.157)$ \\
\hline Aonly_FTC & 0.012 & $(0.232)$ \\
\hline Tonly_IPBox & -0.003 & $(0.762)$ \\
\hline Aonly_IPBox & -0.013 & $(0.266)$ \\
\hline Diff_Xrate & 0.009 & $(0.772)$ \\
\hline Diff_RealRI & $0.025^{*}$ & $(0.094)$ \\
\hline Diff_DisclosureIndex & -0.001 & $(0.618)$ \\
\hline Diff_Anti_SelfDeal & 0.033 & $(0.101)$ \\
\hline MaxTrade & $-0.487 * * *$ & $(0.000)$ \\
\hline Diff_GDP & $0.017 * * *$ & $(0.000)$ \\
\hline Diff_GDPgrowth & 0.001 & $(0.231)$ \\
\hline GCDist & $0.003 * * *$ & $(0.001)$ \\
\hline SameReligion & $-0.029 * * *$ & $(0.005)$ \\
\hline SameLanguage & $-0.039 * * *$ & $(0.000)$ \\
\hline Observations & & \\
\hline Adjusted R-Squared & & \\
\hline Year Fixed Effects & & \\
\hline Acquirer Country Fixed Effects & & \\
\hline Robust SE Clustered by Country & & \\
\hline
\end{tabular}




\section{Table 12: Descriptive Statistics}

Table 12 presents the descriptive statistics for the deal-level premia analyses. All variables are as defined in Appendix A. Premia is shown unlogged for ease of interpretation.

\begin{tabular}{|c|c|c|c|c|c|c|}
\hline \multicolumn{7}{|c|}{ M\&A Premia Observation Sample Descriptives } \\
\hline Variable & $\mathbf{N}$ & Mean & $\begin{array}{l}\text { Standard } \\
\text { Deviation }\end{array}$ & $\mathbf{p}(25)$ & Median & $\mathbf{p}(\mathbf{7 5})$ \\
\hline Premia & 1,518 & 42.152 & 50.581 & 13.060 & 28.288 & 50.160 \\
\hline Diff_Trate_CorpIncTax & 1,518 & 0.681 & 10.342 & -7.000 & 0.000 & 7.880 \\
\hline Diff_Trate_Dividends & 1,518 & 10.218 & 15.096 & 0.000 & 15.000 & 20.000 \\
\hline Aww_Tterr & 1,518 & 0.312 & 0.463 & 0.000 & 0.000 & 1.000 \\
\hline Aterr_Tww & 1,518 & 0.267 & 0.442 & 0.000 & 0.000 & 1.000 \\
\hline Aonly_CFC & 1,518 & 0.325 & 0.468 & 0.000 & 0.000 & 1.000 \\
\hline Tonly_CFC & 1,518 & 0.223 & 0.417 & 0.000 & 0.000 & 0.000 \\
\hline Aonly_ThinCap & 1,518 & 0.235 & 0.424 & 0.000 & 0.000 & 0.000 \\
\hline Tonly_ThinCap & 1,518 & 0.271 & 0.444 & 0.000 & 0.000 & 1.000 \\
\hline Aonly_TP & 1,518 & 0.041 & 0.198 & 0.000 & 0.000 & 0.000 \\
\hline Tonly_TP & 1,518 & 0.052 & 0.222 & 0.000 & 0.000 & 0.000 \\
\hline Tonly_FTC & 1,518 & 0.134 & 0.340 & 0.000 & 0.000 & 0.000 \\
\hline Aonly_FTC & 1,518 & 0.090 & 0.286 & 0.000 & 0.000 & 0.000 \\
\hline Tonly_IPBox & 1,518 & 0.066 & 0.248 & 0.000 & 0.000 & 0.000 \\
\hline Aonly_IPBox & 1,518 & 0.102 & 0.303 & 0.000 & 0.000 & 0.000 \\
\hline Diff_Xrate & 1,518 & -0.004 & 0.104 & -0.064 & 0.000 & 0.059 \\
\hline Diff_RealRI & 1,518 & 0.015 & 0.171 & -0.075 & 0.011 & 0.109 \\
\hline Diff_DisclosureIndex & 1,518 & -0.530 & 2.538 & -2.000 & -0.400 & 1.000 \\
\hline Diff_Anti_SelfDeal & 1,518 & -0.045 & 0.264 & -0.243 & -0.015 & 0.156 \\
\hline MaxTrade & 1,518 & 0.125 & 0.200 & 0.017 & 0.048 & 0.132 \\
\hline Diff_GDP & 1,518 & 0.233 & 1.309 & -0.204 & 0.053 & 0.394 \\
\hline Diff_GDPgrowth & 1,518 & -0.253 & 2.854 & -1.498 & -0.127 & 1.035 \\
\hline GCDist & 1,518 & 6.502 & 4.976 & 1.184 & 6.168 & 9.559 \\
\hline SameReligion & 1,518 & 0.688 & 0.464 & 0.000 & 1.000 & 1.000 \\
\hline SameLanguage & 1,518 & 0.323 & 0.468 & 0.000 & 0.000 & 1.000 \\
\hline SameIndustry & 1,518 & 0.566 & 0.496 & 0.000 & 1.000 & 1.000 \\
\hline Gov_Involvement & 1,518 & 0.043 & 0.203 & 0.000 & 0.000 & 0.000 \\
\hline Unsolicited & 1,518 & 0.017 & 0.130 & 0.000 & 0.000 & 0.000 \\
\hline $\operatorname{BigN}$ & 1,518 & 0.030 & 0.170 & 0.000 & 0.000 & 0.000 \\
\hline Private & 1,518 & 0.088 & 0.283 & 0.000 & 0.000 & 0.000 \\
\hline Size & 1,518 & 4.148 & 2.310 & 2.398 & 4.080 & 5.769 \\
\hline CompetingBid & 1,518 & 0.024 & 0.154 & 0.000 & 0.000 & 0.000 \\
\hline ToeHold & 1,518 & 10.007 & 23.439 & 0.000 & 0.000 & 0.100 \\
\hline
\end{tabular}




\section{Table 13: Determinants of Merger Premia Cross-Border M\&A}

Table 13 presents the results of the Ordinary Least Squares Regression of model (5) using Log_Premia as the dependent variable. Each observation is a M\&A transaction. Fixed effects are suppressed for brevity. All variables are defined in Appendix A. P-values are presented in parentheses in Column (2). * **, and *** indicate significance at the $0.10,0.05$, and 0.01 levels, respectively (based on two-tailed tests).

\begin{tabular}{|c|c|c|}
\hline VARIABLES & $\begin{array}{c}\text { (1) } \\
\text { Coefficient }\end{array}$ & $\begin{array}{c}(2) \\
\text { p-value }\end{array}$ \\
\hline Diff_Trate_CorpIncTax & 0.001 & $(0.861)$ \\
\hline Diff_Trate_Dividends & -0.002 & $(0.604)$ \\
\hline Aww_Tterr & 0.119 & $(0.193)$ \\
\hline Aterr_Tww & $0.226 * *$ & $(0.017)$ \\
\hline Aonly_CFC & -0.009 & $(0.935)$ \\
\hline Tonly_CFC & 0.080 & $(0.423)$ \\
\hline Aonly_ThinCap & -0.003 & $(0.980)$ \\
\hline Tonly_ThinCap & 0.071 & $(0.470)$ \\
\hline Aonly_TP & $-0.401 * *$ & $(0.043)$ \\
\hline Tonly_TP & 0.060 & $(0.686)$ \\
\hline Tonly_FTC & -0.047 & $(0.665)$ \\
\hline Aonly_FTC & -0.126 & $(0.434)$ \\
\hline Tonly_IPBox & 0.065 & $(0.716)$ \\
\hline Aonly_IPBox & -0.004 & $(0.973)$ \\
\hline Diff_Xrate & 0.195 & $(0.536)$ \\
\hline Diff_RealRI & 0.233 & $(0.300)$ \\
\hline Diff_DisclosureIndex & 0.011 & $(0.644)$ \\
\hline Diff_Anti_SelfDeal & $-0.418 *$ & $(0.089)$ \\
\hline MaxTrade & $0.202 * *$ & $(0.036)$ \\
\hline Diff_GDP & -0.160 & $(0.111)$ \\
\hline Diff_GDPgrowth & -0.005 & $(0.595)$ \\
\hline GCDist & 0.231 & $(0.443)$ \\
\hline SameReligion & -0.047 & $(0.205)$ \\
\hline SameLanguage & -0.007 & $(0.682)$ \\
\hline SameIndustry & $0.180 * * *$ & $(0.008)$ \\
\hline Gov_Involvement & -0.275 & $(0.108)$ \\
\hline Unsolicited & $0.501 * * *$ & $(0.002)$ \\
\hline $\operatorname{BigN}$ & -0.040 & $(0.797)$ \\
\hline Private & -0.171 & $(0.345)$ \\
\hline Size & 0.179 & $(0.106)$ \\
\hline
\end{tabular}


CompetingBid

ToeHold

Observations

Adjusted R-Squared

Year Fixed Effects

Acquirer Country Fixed Effects

Robust SE Clustered by Country
0.018

$-0.003^{*}$

$(0.261)$

(0.059)

1,518

0.048

YES

YES

YES 


\section{Appendix 2: Extension of Erel et al. (2012)}

This table presents the results of the Ordinary Least Squares Regression of model (2) using CBMA_Erel as the dependent variable. Fixed effects are suppressed for brevity. All variables are defined in Appendix A. P-values are presented in parentheses in Column (2). *,**, and *** indicate significance at the $0.10,0.05$, and 0.01 levels, respectively (based on two-tailed tests).

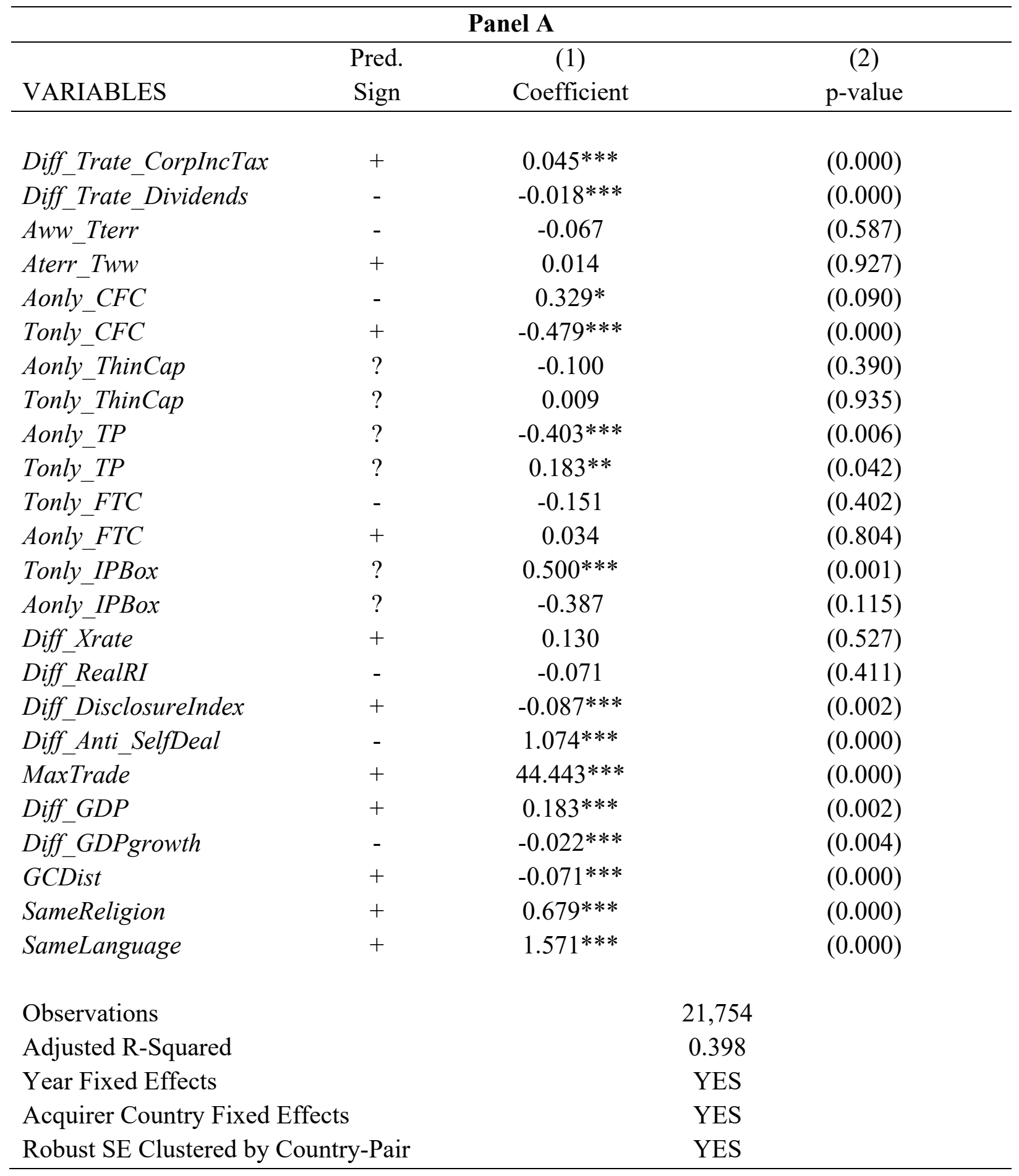


Appendix 2: Extension of Erel et al. (2012) (cont.)

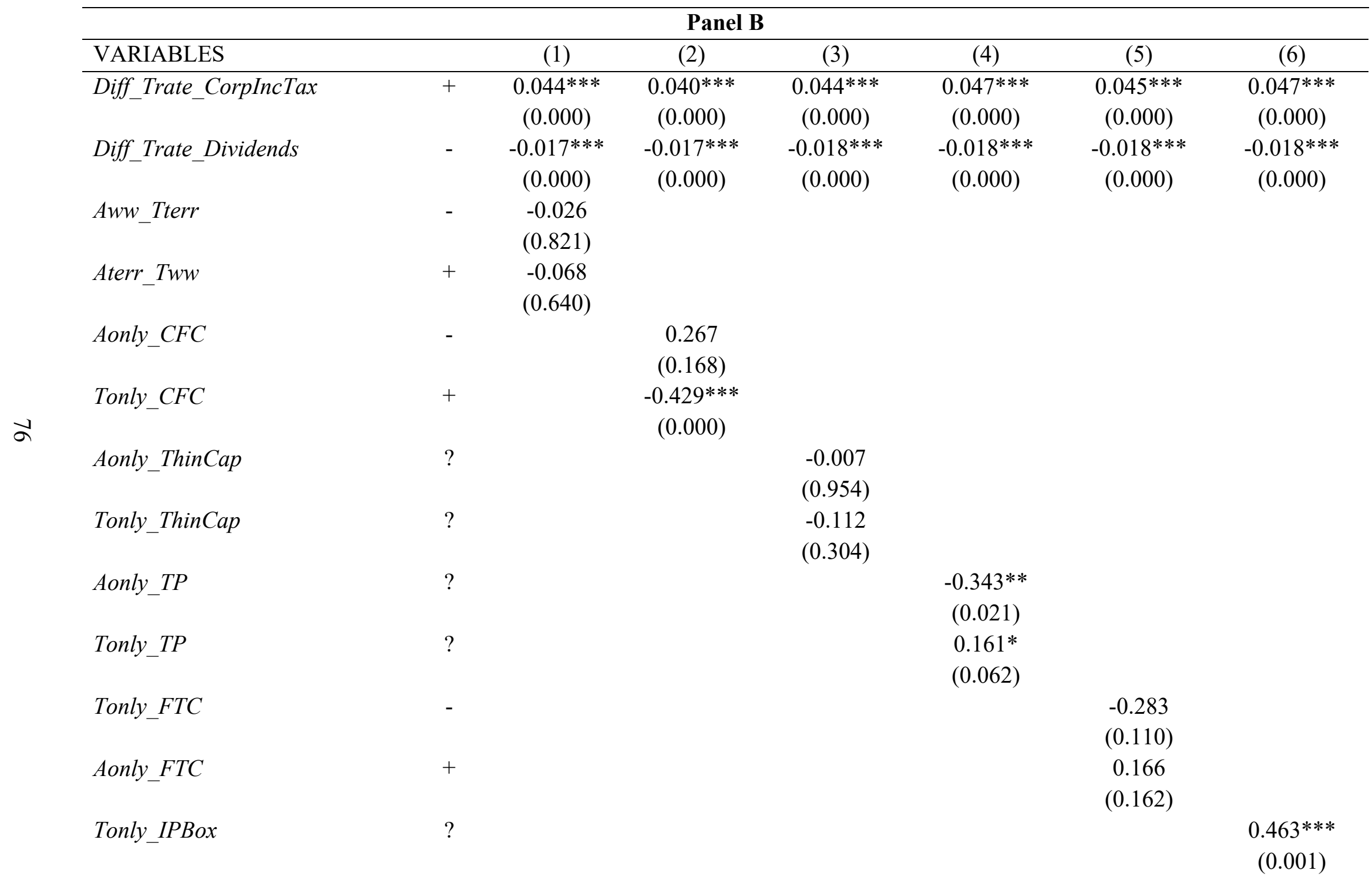


Diff_Xrate

$+$

Diff_RealRI

Diff_DisclosureIndex

$(0.547)$

$$
0.166
$$

0.124

0.116

0.091

(0.114)

$-\quad-0.075$

$$
\text { (0.413) }
$$

$$
(0.540)
$$

$(0.568)$

(0.655)

0.104

$\begin{array}{ccc} & (0.384) & (0.487) \\ + & -0.078 * * * & -0.088 * * *\end{array}$

$-0.060$

$-0.070$

$-0.076$

$-0.084$

(0.606)

(0.414)

Diff_Anti_SelfDeal

$\begin{array}{ccc} & (0.004) & (0.002) \\ - & 1.145^{* * *} & 1.195 * * *\end{array}$

$-0.079 * * *$

(0.373)

(0.005)

$-0.078^{* * *}$

(0.332)

$-0.088^{* * *}$

$-0.076$

(0.000)

$1.168^{* * *}$

(0.005)

(0.001)

(0.375)

MaxTrade

$+\quad 44.300 * * *$

(0.000)

(0.000)

$1.150 * * *$

$1.243 * * *$

$-0.075^{* * *}$

$(0.000)$

Diff_GDP

Diff_GDPgrowth

GCDist

SameReligion

$44.423 * * *$

(0.000)

$+$

$0.183^{* * *}$

(0.000)

(0.000)

$44.353^{* * *}$

(0.000)

(0.007)

$\begin{array}{ccc}(0.001) & (0.018) \\ - & -0.023 * * * & -0.016^{* *}\end{array}$

$0.179^{* * *}$

(0.000)

$44.475 * * *$

(0.001)

$(0.004) \quad(0.036)$

(0.001)

$-0.022 * * *$

(0.006)

$+\quad-0.071^{* * *}$

$-0.072 * * *$

$-0.071 * * *$

$0.206^{* * *}$

(0.000)

$44.598 * * *$

$(0.000)$

(0.000)

$(0.000)$

$+$

$0.580 * * *$

$0.644 * * *$

$0.584 * * *$

$(0.000)$

$-0.025 * * *$

(0.002)

$0.179 * * *$

$(0.000)$

SameLanguage

$(0.000)$

$(0.000)$

$(0.000)$

$1.582 * * * \quad 1.574 * * *$

$1.596 * * *$

$-0.074 * * *$

(0.000)

$0.612 * * *$

$(0.001)$

$-0.023 * * *$

$(0.005)$

$0.210 * * *$

(0.000)

(0.000)

(0.000)

$(0.000)$

$1.583 * * *$

$-0.070 * *$

$(0.000)$

$0.578 * * *$

(0.000)

$-0.026 * * *$

(0.001)

21,75

21,754

Adjusted R-Squared

0.394

21,754
0.394
YES
YES
YES

(0.000)

$(0.000)$

$1.591 * * *$

$-0.067 * * *$

$(0.000)$

$0.571 * * *$

$(0.000)$

$1.607 * * *$

(0.000) (0.000)

Year Fixed Effects

YES

0.396

21,754

21,754

21,754

Acquirer Country Fixed Effects

YES

YES

0.395

0.395

0.396

Robust SE Clustered by Country-Pair

YES

YES

YES

YES

YES

YES

YES

YES

YES 